\title{
IMPROVED ELECTROLYTES FOR FUEL CELLS
}

FInal Report
By
G. L. Gard
D. K. Roe

June 1991

Work Performed Under Contract No. FG21-88MC25142

For

U.S. Department of Energy Morgantown Energy Technology Center Morgantown, West Virginia

By

Portland State University

Portland, Oregon 


\section{DISCLAIMER}

This report was prepared as an account of work sponsored by an agency of the United States Government. Neither the United States Government nor any agency thereof, nor any of their employees, makes any warranty, express or implied, or assumes any legal liability or responsibility for the accuracy, completeness, or usefulness of any information, apparatus, product, or process disclosed, or represents that its use would not infringe privately owned rights. Reference herein to any specific commercial product, process, or service by trade name, trademark, manufacturer, or otherwise does not necessarily constitute or imply its endorsement, recommendation, or favoring by the United States Government or any agency thereof. The views and opininns of authors ex. pressed herein do not necessarily state or reflect those of the United States Government or any agency thereof.

This report has been reproduced directly from the best available copy.

Available to DOE and DOE contractors from the Office of Scientific and Technical Information, P.O. Box 62, Oak Ridge, TN 37831; prices available from (615)576.8401, FTS 626.8401.

Available to the public from the National Technical Information Service, U.S. Department of Commerce, 5285 Port Royal Rd., Springfield, VA 22161. 


\title{
Improved Electrolytes for Fuel Cells
}

\author{
Final Report
}

\author{
G.L. Gard \\ D.K. Roe
}

Work Performed Under Contract No.: DE-FG21-88MC25142

\author{
For \\ U.S. Department of Energy \\ Office of Fossil Energy \\ Morgantown Energy Technology Center \\ P.O. Box 880 \\ Morgantown, West Virginia 26507-0880
}

\author{
By \\ Portland State University \\ Department of Chemistry \\ Portland, Oregon 97207-0751
}

June 1991 
Abstract

Page

Executive Summary

List of Figures, Tables and Attachments

5

1.0 Introduction

$\begin{array}{lll}2.0 & \text { Purpose } & 10\end{array}$

$\begin{array}{ll}3.0 \text { Background and Methodology } & 10\end{array}$

4.0 Results and Discussion 11

A. Dr. Gard 11

B. Dr. Roe 15

5.0 Conclusion/Future Work 23

6.0 References 25 


\begin{abstract}
This report documents the final report of the progress of the grant entitled, "Improved Electrolytes for Fuel Cells", and numbered DE-FG21-88MC25142. The report consists of an Introduction, Purpose, Background and Methodology discussion. The results, with appropriate discussion, achieved by Drs. Gard and Roe, are presented along with significant conclusions.
\end{abstract}


Executive Summary

Improved Electrolytes for Fuel Cells

Department of Energy, Morgantown Energy Technology Center

Grant No. DE-FG21-88MC25142

Principal Investigators:

G.L. Gard and D.K. Roe

Department of Chemistry

Portland State University

Portland, OR 97207-0751

Report Period: $\quad$ June 16, 1988 - June 15, 1990

Objectives:

Synthesis and electrochemical evaluation of new fluorosulfonic acids as superior alternatives to phosphoric acid in fuel cells.

Background:

Present day fuel cells based upon hydrogen and oxygen have limited performance due to the use of phosphoric acid as an electrolyte. Improved performance is desirable in electrolyte conductivity, electrolyte management, oxygen solubility and the kinetics of the reduction of oxygen. Attention has turned to fluorosulfonic acids as additives or substitute electrolytes to improve fuel cell performance.

\section{Results During Two Year Period:}

The following structurally modified sulfonic acid systems have been prepared and submitted for evaluation:

Cyciic Sulfonic Acid: $\mathrm{CF}_{3} \mathrm{CF}_{2} \mathrm{C}_{6} \mathrm{~F}_{4} \mathrm{SO}_{3} \mathrm{H}, \mathrm{C}_{6} \mathrm{~F}_{5} \mathrm{SO}_{3} \mathrm{H}$

Ether-Containing Sulfonic Acids: $\mathrm{C}_{4} \mathrm{~F}_{9} \mathrm{OC}_{4} \mathrm{~F}_{8} \mathrm{SO}_{3} \mathrm{H}, \mathrm{HSO}_{3}\left(\mathrm{CF}_{2}\right)_{2} \mathrm{O}\left(\mathrm{CF}_{2}\right)_{2} \mathrm{SO}_{3} \mathrm{H}$ and $\mathrm{HSO}_{3}\left(\mathrm{CF}_{2}\right)_{2} \mathrm{OCF}_{2} \mathrm{O}\left(\mathrm{CF}_{2}\right)_{2} \mathrm{SO}_{3} \mathrm{H}$ 
Pentafluorothio( $\left(\mathrm{SF}_{5}\right)$-Containing Sulfonic Acids:

Ethane Series: $\mathrm{SF}_{5} \mathrm{CH}_{2} \mathrm{CH}_{2} \mathrm{SO}_{3} \mathrm{H}, \mathrm{SF}_{5} \mathrm{CH}_{2} \mathrm{CF}_{2} \mathrm{SO}_{3} \mathrm{H}$ and $\mathrm{SF}_{5} \mathrm{CHFCF}_{2} \mathrm{SO}_{3} \mathrm{H}$

Methane Series: $\mathrm{SF}_{5} \mathrm{CHFSO}_{3} \mathrm{H}$ and $\mathrm{SF}_{5} \mathrm{CF}_{2} \mathrm{SO}_{3} \mathrm{H}$

Other Acids: $\left(\mathrm{CF}_{3} \mathrm{SO}_{2}\right)_{2} \mathrm{CH}_{2},\left(\left(\mathrm{CF}_{3}\right)_{2} \mathrm{C}-\mathrm{O}\right)_{4}-\mathrm{POH}$

All of these acids and a commercial sample of $\mathrm{CF}_{3} \mathrm{SO}_{3} \mathrm{H}$ were electrochemically evaluated relative to $\mathrm{H}_{3} \mathrm{PO}_{4}$ for oxygen reduction characteristics of significance in possible fuel cell applications. Seven of the acids were also evaluated as additives to $\mathrm{H}_{3} \mathrm{PO}_{4}$ which might improve oxygen solubility-diffusivity. 
List of Figures

Figure 1. HPLC separation of $\mathrm{CH}_{2} \mathrm{Cl}_{2}$ extract of $0.081 \mathrm{M}$ phosphoric acid (Supurapur), $\mathrm{CH}_{2} \mathrm{Cl}_{2}-\mathrm{CH}_{3} \mathrm{CN}$ eluent.

Figure 2. HPLC separation of $\mathrm{CH}_{2} \mathrm{Cl}_{2}$ extract of $0.081 \mathrm{M}$ phosphoric acid (Supurapur) after first purification with $\mathrm{H}_{2} \mathrm{O}_{2}, \mathrm{CH}_{2} \mathrm{Cl}_{2}-\mathrm{CH}_{3} \mathrm{CN}$ eluent.

Figure 3. Ion chromatogram of $0.081 \mathrm{M}$ phosphoric acid, carbonate-bicarbonate eluent.

Figure 4. Cyclic voltammogram of Pt electrode in $0.117 \mathrm{M}$ phosphoric acid, oxygen-free, $100 \mathrm{mV} / \mathrm{s}$, thin solution layer cell.

Figure 5. Cyclic voltammogram of Pt electrode in $0.961 \mathrm{M}$ phosphoric acid, oxygen-free, $100 \mathrm{mV} / \mathrm{s}$, thin solution layer cell.

Figure 6. Cyclic voltammogram of $\mathrm{Pt}$ electrode in $10.1 \mathrm{M}$ phosphoric acid, oxygen-free $100 \mathrm{mV} / \mathrm{s}$, thin solution layer cell.

Figure 7. Voltammogram of oxygen reduction from saturated solution at $\mathrm{Pt}$ electrode in $0.117 \mathrm{M}$ phosphoric acid and background voltammogram, $100 \mathrm{mV} / \mathrm{s}$, thin solution layer cell.

Figure 8. Voltammogram of oxygen reduction from saturated solution at Pt electrode in $0.961 \mathrm{M}$ phosphoric acid and background voltammogram, $100 \mathrm{mV} / \mathrm{s}$, thin solution layer cell.

Figure 9. Voltammogram of oxygen reduction from saturated solution at Pt electrode in $10.1 \mathrm{M}$ phosphoric acid and background voltammogram, $100 \mathrm{mV} / \mathrm{s}$, thin solution layer cell.

Figure 10. Voltammogram of oxygen reduction from saturated solution at $\mathrm{Pt} \mathrm{RDE}$ in $0.081 \mathrm{M}$ phosphoric acid, $100 \mathrm{mV} / \mathrm{s}$.

Figure 11. Cyclic voltammogram of $0.089 \mathrm{M} \mathrm{C}_{2} \mathrm{~F}_{5}\left(\mathrm{C}_{6} \mathrm{~F}_{10}\right) \mathrm{SO}_{3} \mathrm{H}$ at $\mathrm{Pt}$ electrode in TSLC, $100 \mathrm{mV} / \mathrm{s}$. 
Figure 12. Cyclic voltammogram of $0.386 \mathrm{M} \mathrm{SF}_{5} \mathrm{CHFSO}_{3} \mathrm{H}$ at Pt electrode in TSLC, $100 \mathrm{mV} / \mathrm{s}$.

Figure 13. Cyclic voltammogram of $0.12 \mathrm{M} \mathrm{SF}_{5} \mathrm{CF}_{2} \mathrm{SO}_{3} \mathrm{H}$ at $\mathrm{Pt}$ electrode in TSLC, $100 \mathrm{mV} / \mathrm{s}$.

Figure 14. Ion chromatrogram of $0.02 \mathrm{M} \mathrm{SF}_{5} \mathrm{CH}_{2} \mathrm{CH}_{2} \mathrm{SO}_{3} \mathrm{H}$, carbonate-bicarbonate eluent.

Figure 15. Cyclic voltammogram of $0.192 \mathrm{M} \mathrm{SF}_{5} \mathrm{CH}_{2} \mathrm{CH}_{2} \mathrm{SO}_{3} \mathrm{H}$ at $\mathrm{Pt}$ electrode in TSLC, $100 \mathrm{mV} / \mathrm{s}$.

Figure 16. Cyclic voltammogram of $0.060 \mathrm{M} \mathrm{SF}_{5} \mathrm{CH}_{2} \mathrm{CF}_{2} \mathrm{SO}_{3} \mathrm{H}$ at Pt electrode in TSLC, $100 \mathrm{mV} / \mathrm{s}$.

Figure 17. Cyclic voltammogram of $0.101 \mathrm{M} \mathrm{SF}_{5} \mathrm{CHFCF}_{2} \mathrm{SO}_{3} \mathrm{H}$ at Pt electrode in TSLC, $100 \mathrm{mV} / \mathrm{s}$.

Figure 18. Cyclic voltammogram of $0.125 \mathrm{M} \mathrm{C}_{4} \mathrm{~F}_{9} \mathrm{OC}_{4} \mathrm{~F}_{8} \mathrm{SO}_{3} \mathrm{H}$ at $\mathrm{Pt}$ electrode in TSLC, $100 \mathrm{mV} / \mathrm{s}$.

Figure 19. Cyclic voltammogram of $0.259 \mathrm{M} \mathrm{O}\left(\mathrm{CF}_{2} \mathrm{CF}_{2} \mathrm{SO}_{3} \mathrm{H}\right)_{2}$ at $\mathrm{Pt}$ electrode in TSLA, $100 \mathrm{mV} / \mathrm{s}$.

Figure 20. Cyclic voltammogram of $0.128 \mathrm{M} \mathrm{CF}_{2}\left(\mathrm{OCF}_{2} \mathrm{CF}_{2} \mathrm{SO}_{3} \mathrm{H}\right)_{2}$ at $\mathrm{Pt}$ electrode in TSLC, $100 \mathrm{mV} / \mathrm{s}$.

Figure 21. Cyclic voltammogram of $0.195 \mathrm{M}\left(\mathrm{CF}_{3} \mathrm{SO}_{2}\right)_{2} \mathrm{CH}_{2}$ at $\mathrm{Pt}$ electrode in TSLC, $100 \mathrm{mV} / \mathrm{s}$.

Figure 22. Voltammogram of oxygen reduction from saturated solution at $\mathrm{Pt} R D E$ in $0.195 \mathrm{M}\left(\mathrm{CF}_{3} \mathrm{SO}_{2}\right)_{2} \mathrm{CH}_{2}$ and in $0.081 \mathrm{M} \mathrm{H}_{3} \mathrm{PO}_{4}, 100 \mathrm{mV} / \mathrm{s}$.

Figure 23. Cyclic voltammogram of $0.101 \mathrm{M} \mathrm{CF}_{3} \mathrm{SO}_{3} \mathrm{H}$ at $\mathrm{Ft}$ electrode in TSLC, $100 \mathrm{mV} / \mathrm{s}$.

Figure 24. Cyclic voltammogram of $0.01 \mathrm{M}$ hydroxy-bicyclic phosphate acid at $\mathrm{Pt}$ electrode in TSLC, $100 \mathrm{mV} / \mathrm{s}$. 
Figure 25. Thin solution layer cell (TSLC) for IR reflectance spectroscopy and cyclic voltammetry.

Figure 26. IRRAS difference spectrum of $0.18 \mathrm{M} \mathrm{O}\left(\mathrm{CF}_{2} \mathrm{CF}_{2} \mathrm{SO}_{3} \mathrm{H}\right)_{2}$ in $0.08 \mathrm{M} \mathrm{H}_{3} \mathrm{PO}_{4}$. Reference spectrum taken at $0.15 \mathrm{~V}$.

\author{
List of Tables
}

Table 1. Physical and chemical properties of synthesized acids.

Table 2. Peak currents and potentials of oxygen reduction at Pt electrode in thin solution layer cell. Linear potential scan, $100 \mathrm{mV} / \mathrm{s}$.

Table 3. Peak currents of oxygen reduction at $\mathrm{Pt}$ electrode in thin solution layer cell with mixtures of acids. Linear potential scan, $100 \mathrm{mV} / \mathrm{s}$.

Table 4. Oxygen reduction at $\mathrm{Pt}$ rotating disk electrode, $400 \mathrm{rpm}$.

List of Attachments

Attachment 1. Project Publication List

Attachment 2. Federal Assistance Milestone Plan

Attachment 3. Polymeric Sulfonyl Fluoride Esters/Ethers 


\subsection{Introduction}

There is interest in improving the performance and life of the state of the art phosphoric acid fuel cell (PAFC). The power section of the fuel cell system has an electrolyte (phosphoric acid) which is not ideal. Improvements in conductivity, electrolyte management, and the rate of oxygen reduction are required to accomplish the above improvements. Successful completion of this research will contribute to meeting these goals resulting in a lower cost for electrical power.

\section{$2.0 \quad$ Purpose}

We have initiated a structural study coupled with spectroelectrochemical experiments that will examine the effects of substituents/terminal groups, chain-length and heteroatom structures on the desired properties (listed below) of selected compounds and initiated a study into possible synergistic surface-active systems that can achieve the desired properties of improved fuel cell performance.

\subsection{Background and Methodology}

We will design and synthesize new and known fluorine containing sulfonic acids/salts for use as fuel cell electrolyte additives. This work will entail development of preparative routes to known and new sulfonic acids/salts and synthesizing these compounds in amounts large enough to be tested. These compounds will be evaluated in-house and the most promising compounds will then be tested by a major PAFC DOE contractor. A planned structural/composition study to examine the prepared compounds for the desired properties (stability, acidity, surface activity, oxygen solubility, ionic conductivity) brought about by: substituents/terminal grouping, chain length, preserice of heteroatoms in the chain, and, polysulfonic/polymeric groupings will also be carried out. These factors will be correlated and related to the overall increased efficiency for use in fuel cell electrolytes. The primary emphasis will be on use as an additive to the phosphoric acid electrolyte, however, substitution of this compound as the total eiectrolyte will be considered.

All in-house electrochemical testing of the synthesized compounds was carried out at Portland State University under Dr. Roe's direction. Dr. Roe used some of the standard techniques (rotating ring disk electrode and state-of-the-art gas diffusion electrodes), and a new thin solution layer cell (TSLC) technique so that small samples were rapidly screened. 
The TSLC technique was coupled with infrared reflection-absorption spectroscopy (IRRAS) and fourier transform infrared spectroscopy (FTIR) in identifying impurities in the original synthesized samples. Analysis for impurities by chromatography was also shown to be important.

\subsection{Results and Discussion}

A. Work performed in Dr. Gard's laboratory.

During the two years of this project significant progress, in accordance with the Federal Assistance Milestone Plan (Attachment 2), has been achieved.

Cyclic Acids

The following perfluorocyclic sulfonic acid was prepared for evaluation:

$\left(\mathrm{CF}_{3} \mathrm{CF}_{2} \mathrm{C}_{6} \mathrm{~F}_{4} \mathrm{SO}_{3}\right)_{2} \mathrm{Ca}+\mathrm{H}_{2} \mathrm{SO}_{4} \rightarrow 2 \mathrm{CF}_{3} \mathrm{CF}_{2} \mathrm{C}_{6} \mathrm{~F}_{4} \mathrm{SO}_{3} \mathrm{H}+\mathrm{CaSO}_{4}$

Heteroatoms/Terminal Groupings/Polysulfonic Acids

Previously, a disulfonic acid containing an ether linkage has shown high water solubility and superior activity for oxygen reduction compared to phosphoric acid when used as an additive. Since the structurally modified ether-containing sulfonic acids are highly promising candidates as either additives or as fuel cell electrolytes, we were pleased to report that a significant milestone involving a more direct route to mono/di/poly and polymeric ether-containing sulfonic acid precursors has been reached. This method involved the following:

$$
\begin{aligned}
& \mathrm{RX}+\mathrm{CF}_{2} \mathrm{CF}_{2} \mathrm{OSO}_{2}+\mathrm{MF} \stackrel{\text { Diglyme }}{\longrightarrow} \mathrm{ROCF}_{2} \mathrm{CF}_{2} \mathrm{SO}_{2} \mathrm{~F}+\mathrm{MX} \\
& \mathrm{R}=\mathrm{CF}_{2}=\mathrm{CFCH}_{2} \mathrm{CH}_{2}, \mathrm{SF}_{5} \mathrm{CH}_{2} \mathrm{CH}_{2}, \mathrm{BrCH}_{2} \mathrm{CH}_{2}, \mathrm{CH}_{3} \mathrm{CH}_{2} \mathrm{CH}_{2}, \mathrm{CH}_{2}=\mathrm{CHC}(\mathrm{O}) \text {, } \\
& \mathrm{OCH}_{2} \mathrm{CHCH}_{2},\left(\mathrm{CH}_{3}\right)_{3} \mathrm{SiCH}_{2},\left(\mathrm{CH}_{3} \mathrm{CH}_{2} \mathrm{O}\right)_{2} \mathrm{P}(\mathrm{O}) \mathrm{CH}_{2} \mathrm{Cl}_{2},\left(\mathrm{CF}_{3}\right)_{2} \mathrm{CFCH}_{2} \mathrm{CH}_{2} \text {, } \\
& \mathrm{BrCH}=\mathrm{CHCH}_{2}, \mathrm{CH}_{2}=\mathrm{C}(\mathrm{Br}) \mathrm{CH}_{2}, \mathrm{HC}=\mathrm{CCH}_{2} \text {. } \\
& \mathrm{M}=\mathrm{K}^{+}, \mathrm{Cs}^{+} ; \mathrm{X}=\mathrm{I}, \mathrm{Br} \text {. } \\
& \mathrm{R}^{\prime} \mathrm{X}_{2}+2 \mathrm{CF}_{2} \mathrm{CF}_{2} \mathrm{OSO}_{2}+2 \mathrm{MF} \stackrel{\text { Diglyme }}{\longrightarrow} \mathrm{R}^{\prime}\left(\mathrm{OCF}_{2} \mathrm{CF}_{2} \mathrm{SO}_{2} \mathrm{~F}\right)_{2}+2 \mathrm{MX} \\
& \mathrm{R}^{\prime}=\quad-\mathrm{CH}_{2}^{-},-\mathrm{CH}_{2} \mathrm{CH}_{2}- \\
& \mathrm{M}=\mathrm{Ag}^{+} ; \mathrm{X}=\mathrm{I}, \mathrm{Br} \\
& \text { More recently, this method was expanded to include another sultone: } \\
& \mathrm{RX}+\mathrm{CF}_{3} \mathrm{CFCF}_{2} \mathrm{OSO}_{2}+\mathrm{AgF} \stackrel{\text { Diglyme }}{\longrightarrow} \mathrm{ROCF}_{2} \mathrm{CF}\left(\mathrm{CF}_{3}\right) \mathrm{SO}_{2} \mathrm{~F}
\end{aligned}
$$




\section{$\mathrm{R}=\left(\mathrm{CF}_{3}\right)_{2} \mathrm{CFCH}_{2} \mathrm{CH}_{2}, \mathrm{CF}_{2}=\mathrm{CFCH}_{2} \mathrm{CH}_{2}, \mathrm{OCH}_{2} \mathrm{CHCH}_{2}, \mathrm{CH}_{2}=\mathrm{CBrCH}_{2}, \mathrm{CH}_{3}$, $\mathrm{SF}_{5} \mathrm{CH}_{2} \mathrm{CH}_{2},-\mathrm{CH}_{2}-$}

All of the above structurally modified ether-containing sulfonyl fluorides have been characterized. We have not fully explored the extent to which ether-containing polyand polymeric sulfonyl fluorides and the corresponding sulfonic acius can be prepared. We are confident, however, that a significant milestone has been reached and creates many possibilities for preparing a number of structurally modified sulfonic acids. For example, we have successfully fluorinated the following system:

$$
\mathrm{CH}_{2}\left(\mathrm{OCF}_{2} \mathrm{CF}_{2} \mathrm{SO}_{2}\right)_{2}+\mathrm{F}_{2}+\mathrm{NaF} \rightarrow \mathrm{CF}_{2}\left(\mathrm{OCF}_{2} \mathrm{CF}_{2} \mathrm{SO}_{2}\right)_{2}+2 \mathrm{NaF} \cdot \mathrm{HF}
$$

This material in turn was converted into its corresponding acid $\mathrm{CF}_{2}\left(\mathrm{OCF}_{2} \mathrm{CF}_{2} \mathrm{SO}_{3} \mathrm{H}\right)_{2}$ and submitted for evaluation. This new acid will allow us to compare the following heteroatom (ether) sulfonic acids: $\quad \mathrm{C}_{4} \mathrm{~F}_{9} \mathrm{OC}_{4} \mathrm{~F}_{8} \mathrm{SO}_{3} \mathrm{H}, \quad \mathrm{HSO}_{3}\left(\mathrm{CF}_{2}\right)_{2} \mathrm{O}\left(\mathrm{CF}_{2}\right)_{2} \mathrm{SO}_{3} \mathrm{H}$, and $\mathrm{HSO}_{3} \mathrm{CF}_{2} \mathrm{CF}_{2} \mathrm{OCF}_{2} \mathrm{CF}_{2} \mathrm{SO}_{3} \mathrm{H}$ as fuel cell electrolytes. The other acids in this group have also been prepared and submitted for evaluation. It is also possible to prepare a number of ether containing sulfonyl fluorides from $\mathrm{I}\left(\mathrm{CF}_{2}\right)_{2} \mathrm{O}\left(\mathrm{CF}_{2}\right)_{2} \mathrm{SO}_{2} \mathrm{~F}$ :

$$
\begin{aligned}
& \mathrm{I}\left(\mathrm{CF}_{2}\right)_{2} \mathrm{O}\left(\mathrm{CF}_{2}\right)_{2} \mathrm{SO}_{2} \mathrm{~F}+\mathrm{xs} \cdot \mathrm{H}_{2} \mathrm{C}=\mathrm{CH}_{2} \stackrel{\mathrm{Bz}_{2} \mathrm{O}_{2}}{\mathrm{n}}>\mathrm{I}\left(\mathrm{CH}_{2}\right)_{\mathrm{n}}\left(\mathrm{CF}_{2}\right)_{2} \mathrm{O}\left(\mathrm{CF}_{2}\right)_{2} \mathrm{SO}_{2} \mathrm{~F} \\
& \mathrm{n}=2,4 \\
& \mathrm{I}\left(\mathrm{CF}_{2}\right)_{2} \mathrm{O}\left(\mathrm{CF}_{2}\right)_{2} \mathrm{SO}_{2} \mathrm{~F}+\mathrm{HC} \cdot \mathrm{CH} \rightarrow \mathrm{ICH}=\mathrm{CH}\left(\mathrm{CF}_{2}\right)_{2} \mathrm{O}\left(\mathrm{CF}_{2}\right)_{2} \mathrm{SO}_{2} \mathrm{~F} \\
& \mathrm{I}\left(\mathrm{CH}_{2}\right)_{2}\left(\mathrm{CF}_{2}\right)_{2} \mathrm{O}\left(\mathrm{CF}_{2}\right)_{2} \mathrm{SO}_{2} \mathrm{~F}+\mathrm{Et}_{3} \mathrm{~N} \rightarrow \mathrm{CH}_{2}=\mathrm{CH}\left(\mathrm{CF}_{2}\right)_{2} \mathrm{O}\left(\mathrm{CF}_{2}\right)_{2} \mathrm{SO}_{2} \mathrm{~F}+\mathrm{HEt}_{3} \mathrm{NI}(8)
\end{aligned}
$$

\section{Terminal Groupings}

Pentafluorothio $\left(\mathrm{SF}_{5}\right)$ sulfonic acids show promise as additives or as fuel celi electrolytes; short-chain monosulfonic acids containing a terminal $\mathrm{SF}_{5}$ group have been found to possess high conductivities and good water solubility. Since sulfonic acids containing terminal $\mathrm{SF}_{5}$ groups have shown exceptional promise as additives or fuel cell electrolytes, we have undertaken a successful program of study during the two years of the grant.

In our attempt to prepare new pentafluorothio( $\left.\mathrm{SF}_{5}\right)$-containing sulfonic acids, it was found that the highly reactive ketene, $\mathrm{F}_{5} \mathrm{SC}\left(\mathrm{SO}_{2} \mathrm{~F}\right)=\mathrm{C}=\mathrm{O}$, was produced: 


$$
\mathrm{F}_{5} \mathrm{SCHCF}_{2} \mathrm{OSO}_{2} \stackrel{\mathrm{NaF}}{\longrightarrow} \stackrel{\mathrm{F}_{3} \mathrm{~B} \cdot \mathrm{N}\left(\mathrm{C}_{2} \mathrm{H}_{5}\right)_{3}}{\longrightarrow} \mathrm{F}_{5} \mathrm{SC}\left(\mathrm{SO}_{2} \mathrm{~F}\right)=\mathrm{C}=\mathrm{O}
$$

The new ketene was found to react with alcohols to generate new and known fluoroesters in high yields:

$$
\mathrm{F}_{5} \mathrm{SC}\left(\mathrm{SO}_{2} \mathrm{~F}\right)=\mathrm{C}=\mathrm{O}+\mathrm{ROH} \rightarrow \mathrm{F}_{5} \mathrm{SCH}\left(\mathrm{SO}_{2} \mathrm{~F}\right) \mathrm{C}(\mathrm{O}) \mathrm{OR}
$$

These esters can serve as precursors to new structurally modified termial grouping/ethercontaining fluorosulfonic acids.* They can be prepared by the following route:

$\mathrm{F}_{5} \mathrm{SCH}\left(\mathrm{SO}_{2} \mathrm{~F}\right) \mathrm{C}(\mathrm{O}) \mathrm{OR} \stackrel{\mathrm{HF}^{2} \mathrm{SF}_{4}}{\longrightarrow} \mathrm{F}_{5} \mathrm{SCH}\left(\mathrm{SO}_{2} \mathrm{~F}\right) \mathrm{CF}_{2} \mathrm{OR} \frac{1) \mathrm{OH}^{-}}{2) \mathrm{H}^{+}} \rightarrow \mathrm{F}_{5} \mathrm{SCH}\left(\mathrm{SO}_{3} \mathrm{H}_{2}, \mathrm{CF}_{2} \mathrm{OR}\right.$

A number of $\mathrm{SF}_{5}$ terminal sulfonic acids have been prepared and s'sbmitted for evaluation. These acids were prepared according to the following equations:

$$
\begin{aligned}
& \mathrm{F}_{5} \mathrm{SCXYCY}_{2} \mathrm{Br}+\mathrm{Na}_{2} \mathrm{SO}_{3} \stackrel{50 \% \mathrm{EtOH}}{\rightarrow} \mathrm{F}_{5} \mathrm{SCXYCY}_{2} \mathrm{SO}_{3} \mathrm{Na}+\mathrm{NaBr} \\
& \mathrm{F}_{5} \mathrm{SCXYCY}_{2} \mathrm{SO}_{3} \mathrm{Na}+\text { xs. } \mathrm{HCl} \rightarrow \mathrm{F}_{5} \mathrm{SCXYCY}_{2} \mathrm{SO}_{3} \mathrm{H}+\mathrm{NaCl}_{(\mathrm{s})} \\
& \mathrm{X}=\mathrm{H}, \mathrm{F} ; \mathrm{Y}=\mathrm{H}, \mathrm{F}
\end{aligned}
$$

In this manner, th: = following $\mathrm{SF}_{5}$ acids have been prepared: $\mathrm{SF}_{5} \mathrm{CH}_{2} \mathrm{CH}_{2} \mathrm{SO}_{3} \mathrm{H}, \mathrm{SF}_{5} \mathrm{CH}_{2} \mathrm{CF}_{2} \mathrm{SO}_{3} \mathrm{H}$, and $\mathrm{SF}_{5} \mathrm{CHFCF}_{2} \mathrm{SO}_{3} \mathrm{H}$.

In a different route, two more $\mathrm{SF}_{5}$ acids have been prepared:

$$
\begin{aligned}
& \mathrm{F}_{5} \mathrm{SCFCF}_{2} \mathrm{OSO}_{2}+\mathrm{H}_{2} \mathrm{O} \rightarrow \frac{1) \mathrm{OH}^{-}}{2) \mathrm{H}^{+}} \mathrm{SF}_{5} \mathrm{CFHSO}_{3} \mathrm{H} \\
& \mathrm{F}_{5} \mathrm{SCHCF}_{2} \mathrm{OSO}_{2}+\mathrm{H}_{2} \mathrm{O} \rightarrow \frac{1) \mathrm{HO}^{-}}{2) \mathrm{H}^{+}} \mathrm{SF}_{5} \mathrm{CH}_{2} \mathrm{SO}_{3} \mathrm{H}
\end{aligned}
$$

* In general, a large number of esters containing other terminal groups have also been prepared from $\beta$-fluorosultones and alcohols or from RX and $\left.\mathrm{AgOC}^{\prime} \mathrm{O}\right) \mathrm{CF}_{2} \mathrm{SO}_{2} \mathrm{~F}$; in particular, allyl esters (mono/di allyl groupings) which were subsequently polymerized. However, because of the more direct pathway to ether containing sulfonic acids precursors, the alcohol-sultone method has not been fully explored or studied. 
Recently, another milestone was reached by the first successful preparation of a $\mathrm{SF}_{5}$ containing perfluorinated sulfonic acid:

$$
\mathrm{SF}_{5} \mathrm{CHFSO}_{2} \mathrm{~F} \frac{\mathrm{F}_{2}}{\mathrm{NaF}} \longrightarrow \mathrm{SF}_{5} \mathrm{CF}_{2} \mathrm{SO}_{2} \mathrm{~F} \frac{1) \mathrm{OH}^{-}}{2) \mathrm{H}^{+}} \longrightarrow \mathrm{SF}_{5} \mathrm{CF}_{2} \mathrm{SO}_{3} \mathrm{H}
$$

All the above $\mathrm{SF}_{5}$ acids have been submitted for evaluation.

Selected chemical and physical properties of' he fluorosulfonic acids are summarized in Table 1.

\section{Polymeric Sulfonic Acids}

INafion, a polymeric sulfonic acid, has already been commercially used as a fuel cell electrolytes. We have prepared a number of interesting and important Nafion-type precursors; i.e., $\quad \mathrm{HC}-\mathrm{CCH}_{2} \mathrm{OCF}_{2} \mathrm{CF}_{2} \mathrm{SO}_{2} \mathrm{~F}, \quad \mathrm{~F} 2 \mathrm{C}=\mathrm{CFCH}_{2} \mathrm{CH}_{2} \mathrm{OCF}_{2} \mathrm{CF}_{2} \mathrm{SO}_{2} \mathrm{~F}$, $\mathrm{CH}_{2}=\mathrm{CHCH}_{2} \mathrm{O}\left(\mathrm{CF}_{2}\right)_{2} \mathrm{SO}_{2} \mathrm{~F}$ and the reactive intermediates $\mathrm{HCI}=\mathrm{CH}\left(\mathrm{CF}_{2}\right)_{2} \mathrm{O}\left(\mathrm{CF}_{2}\right)_{2} \mathrm{SO}_{2} \mathrm{~F}$ and $\mathrm{H}_{2} \mathrm{C}=\mathrm{CH}\left(\mathrm{CF}_{2}\right)_{2} \mathrm{O}\left(\mathrm{CF}_{2}\right)_{2} \mathrm{SO}_{2} \mathrm{~F}$.

It is thought that polymeric sulfonyl fluoride polymers can be prepared from these precursors. We have already prepared the following polymeric sulfonyl fluoride:

$$
\mathrm{H}_{2} \mathrm{C}=\mathrm{CHCH}_{2} \mathrm{OCF}_{2} \mathrm{CF}_{2} \mathrm{SO}_{2} \mathrm{~F} \stackrel{\text { uv }}{\longrightarrow}+\left(\mathrm{CH}_{2} \mathrm{CHCH}_{2} \mathrm{OCF}_{2} \mathrm{CF}_{2} \mathrm{SO}_{2} \mathrm{~F}\right)_{\mathrm{n}}
$$

Fluorination of this polymer will give polyfluorosulfonyl fluoride polymers which can easily be converted into the corresponding polymeric sulfonic acids. See Attachment No. 3 for list of polymeric systems. 
B. Work Performed in Dr. Roe's Laboratory: Electrochemical and Chromatographic Evaluation.

During the two years of this project, thirteen acids were tested for purity by high performance liquid chromatography (HPLC), ion chromatography (IC), titration with $\mathrm{NaOH}$, cyclic voltammetry, and rotating disk electrode (RDE) voltammetry. Conductivities were measured in the IC detector cell at room temperature $\left(22-24^{\circ} \mathrm{C}\right)$ and are listed in Table 1 . Oxygen aduction characteristics at a platinum electrode in a thin solution layer cell (TSLC) were measured and compared with phosphoric acid, under conditions of linear potential scans. Details of the TSCL are given in the section un IRRAS measurements. For routine voltammetry, the prism was replaced by a glass plate with an evaporated platinum coating; the platinum served as a counter electrode. The solution layer thickness was set at $0.15 \mathrm{~mm}$. Seven of the acids were further evaluatec as additives to a range of concentrations of phosphoric acid in a search for improved oxygen solubility and diffusivity, that is, additive or synergistic effects.

Purification techniques included sublimation, recrystallization, and oxidative treatment with hydrogen peroxide. In general, it was found that the latter was very effective in the removal of organic impurities, as detected by extraction with methylene chloride and separation with reverse phase HPLC, using photometric detection at $254 \mathrm{~nm}$. Oxidation with hydrogen peroxide, in various modifications, has been used to purify acids for electrochemical use since about 1975 (1). We originated the use of HPLC to monitor the organic impurity concentrations and found that temperatures close to the boiling point of the dilute fluorosulfonic acid solutions were necessary for effective oxidation. Further, the subsequent use of finely divided platinum and hydrogen gas (1) did not improve the purity of our samples. What we did find was that traces of hydrogen peroxide were difficult to remove by boiling and that these low concentrations of hydrogen peroxide seriously interferred with oxygen reduction measurements in the dilute acids. Oxygen has a solubility of about $0.2 \mathrm{mM}$ in dilute acid solutions, so to avoid interference it is necessary that the residual hydrogen peroxide concentration be less than $2 \mathrm{uM}$ ! When this interference was recognized, it became necessary to repeat most of the measurements. Traces of hydrogen peroxide were most easily removed by boiling the solution for several hours with a large platinum gauze; clearly, removal of the gauze is much easier than removal of finely divided platinum by filtration. The use of hydrogen gas had no significant effect in the few cases in which it was tried.

Ion chromatography revealed that most of the acids contained fluoride and chloride in concentrations ranging from 0.02 to $7.7 \%$, as estimated from relative peak areas. Several other anionic peaks, including suifate, were observed in some samples and the other peaks remain unidentified. Phosphoric acid was found to be very pure in terms of anionic impurities; small peaks (relative areas less than $0.01 \%$ ) were identified as complexes of 'sarium and calcium. It is probable that chloride impurities had a deleterious effect on oxygen reduction, but the point was not pursued. A few examples of HPLC and IC results are given under the d scussion of individual acids. 
Within the time and resource constraints of this project, it was concluded that additive/synergistic effects of the acids on the reduction of oxygen in phosphoric acid would be the best indicator of possible improvements in fuel cell applications. There are several reasons for this conclusion: so far, a large number of acids has been evaluated by this group and others with no clear indication that any of the new fluorosulfonic acids fits the requirements as a viable replacement for phosphoric acid in a fuei cell; solubilities of the new acids have been generally too low to allow operation of a fuel cell at the required temperatures (ca. $180^{\circ} \mathrm{C}$ ); when tested at the necessary lower temperatures in microfuel cell, none of the acids, with the exception of $\left(\mathrm{CF}_{3} \mathrm{SO}_{2}\right)_{2} \mathrm{CH}_{2}$ (2), has shown any exceptional performance improvements over phosphoric acid at the same timperature. It should be noted, however, that another research group (3) did not find that this acid exhibited improved solubility and kinetics, perhaps due to impurities. Therefore it follow's at this time that if any of these acids are to fill a role in the improvement of fuel cell performance, it would be as additives to phosphoric acid. The expected effect would be to increase the solubility of oxygen and any increase will proportionally increase the power output of a fuel cell. It is possible that oxygen overpotential may be affected as well, as suggested by Racaqu, et al. (4) in their study of the additive effects of of the highly surface active $\mathrm{CF}_{3} \mathrm{SO}_{2} \mathrm{~N}(\mathrm{H}) \mathrm{SO}_{2} \mathrm{C}_{4} \mathrm{~F}_{9}$; the formation of a "dry caven reaction site of the electrode surface was suggested as the reason for a $70 \mathrm{mV}$ shift in oxygen reduction potential. Many of the acids prepared for this project are not so highily surface active, so the major effect expected would be in solubility/diffusivity. In any event, the direct manner to measure additive effects with small amounts of acids is as additives to phosphoric acid in the TSLC and determine the peak current resulting from a linear potential scan. Seven of the acids have been so evaluated.

The procedure for the search for additive/synergistic effects was to add small volumes ( 0.2 to $0.5 \mathrm{~mL}$ ) of the solutions of the acids, typically $0.1 \mathrm{M}$, to oxygen saturatcd solutions of phosphoric acid and compare the peak currents and potentials obtained with a linear potential scan from the potential where there is zero current in a presence of oxygen, typically $0.95 \mathrm{~V}$ vs. RHE. Corrections for background currents due to capacitive currents and the small amount of surface oxide formed at the initial potential were obtained from similar measurements in , xygen-free solutions. Also, the dilution effect was measured by adding pure water to phosphoric acid solutions saturated with oxygen. This procedure has the advantage that solid samples of the acids are not required. The phosphoric acid solutions were $0.12,0.96$ and $10.1 \mathrm{M}$, corresponding to $1.14,8.96$ and $66.0 \mathrm{wt}$. \%, respectively. By using a wide range of concentrations, any synergistic effects would become noticeable.

\section{Phosphoric acid.}

"Supurapur" grade phosphoric acid contains many organic impurities which can be extracted irto methylene chloride. Figure 1 shows that these impurites are separated on a reverse 
phase HPLC column. After the first treatment with hydrogen peroxide, the majority of the peaks are gone or decreased, seen in Fig. 2. A second treatment resulted in a clean sample. Similar results were obtained with all of the acids evaluated in this project; no attempt was made to identify the compounds. Ionic impurities were detected by IC; an example of separation of the anionic species in phosphoric acid is given in Fig. 3. The peak at a retention time of $1.55 \mathrm{~min}$ was found to be due to a pyrophosphate or phosphate complex of calcium and barium. With the other acids, generally more peaks were found and at higher realtive areas. Kemoval of these inorganic impurities required sublimation or recrystallization; even so, most of the acids contained inorganic anions as evaluated.

Cyclic potential scans of platinum in $0.12,0.96$ and $10.1 \mathrm{M}$ solutions of purified, oxygen-free phosphoric acid are given in Figs. 4,5 and 6. Compared with examples in the numerous literature reports, these are high quality current-potential curves. Also, the near equality of the respective anodic and cathodic charges further attests to the purity of the samples. Charges due to oxygen adsorption/desorption and hydrogen adsorption/desorption were measured by digital integration from the starting points of the scans to the reversal points; these values are noted on the curves.

Potential scans with oxygen saturated solutions, starting from the point of incipient oxygen reduction are shown for the same solutions in Figs. 7, 8 and 9; backpround scans in the absence of oxygen are included; Table 2 includes these and also results from the other acids. These scans were used in the search for additive or synergistic effects after the addition of dilute solutions of many of the fluorosulfonic acids. If the addition of fluorosulfonic acids increases the solubility and/or the diffusivity, the peak currents will be enhanced (after correction for the effect of dilution due to the added volume).

The results are summarized in Table 3 and will be discussed in the sections on the individual acids. All of these measurements were performed at 22 to $24^{\circ} \mathrm{C}$; it should not be assumed that the sarre relative results would have been obtained at more realistic, fuel cell temperatures.

The RDE results obtained with an oxygen saturated solution of $0.081 \mathrm{M}$ phosphoric acid are shown in Fig. 10. The electrode was fabricated from Macor (Corning machinable ceramic) with a body diameter of $0.6 \mathrm{~cm}$; a platinum wire was fixed in a $0.1 \mathrm{~cm}$ hole through end of the Macor by expansion under pressure (i.e., a rivet). The area of the exposed platinum after polishing to 0.5 micron alumina was $0.0201 \mathrm{~cm}^{2}$. Contact was made to the inside of the electode with a small spring, followed by a wire inside the shaft of the assembly and finally to a copper ring on the outside of the shaft where two carbon rods provided electrical contact to the potentiostat.

The procedure used to obtain the curves of Fig. 10 was to cycle the electrode between ca. 0.1 and $1.5 \mathrm{~V}$ vs. RHE until a steady response was obtained, then set the potential at the zero current value, and record the potential scan from that point to $0.2 \mathrm{~V}$ at a scan rate of $100 \mathrm{mV} \mathrm{s}-1$. 
This procedure was repeated at each rotation rate: 400, 900, 1600 and $2500 \mathrm{rpm}$.

The curves of Fig. 10 show good linearity with the square root of rotation rate in the limiting current region, as predicted by the Levich equation. In all respects, the curves are similar to those reported by other workers over the years. The oxygen half-wave potential is $0.72 \mathrm{~V}$ vs. RHE and the limiting current at $0.35 \mathrm{~V}$ and $400 \mathrm{rpm}$ is $3.3 \mathrm{~mA} \mathrm{~cm}$ and these will be used a reference points in the comparison of the fluorosulfonic acids with phosphoric acid; Table 4 presents a summary of the results. Temperature was $24^{\circ} \mathrm{C}$.

There is an important difference between these two measurements of oxygen reduction: the RDE is much more subject to contamination by low concentrations of residual impurities because they are constantly being swept to the electrode surface. The potential scans of oxygen reduction in the TSLC should be nearly free of interference by impurities because the cell volume, less than 200 microliters, contains a proportionately smaiier amount of the impurities and those that are present will adsorb on the counter electrode which has an area of about $1 \mathrm{~cm}^{2}$. For these reasons, additive/synergistic effects were nut examined using the RDE, rather linear potential scans with the TSLC were used. The solution layer thickness in the TSLC was set at $0.15 \mathrm{~mm}$ so that semi-infinite linear diffusion prevailed.

\section{2. $\mathrm{C}_{6} \mathrm{~F}_{5} \mathrm{SO}_{3} \mathrm{H}$}

Further attempts to purify this acid have not been completely successful; ion chromatography shows an unidentified impurity peak amounting to about $5 \%$ of the total according to peak area. Cyclic voltammetry was not satisfactory; there is excessive current in the oxygen adsorption region. The RDE results are given in Table 4; the oxygen reduction overpotential is $0.04 \mathrm{~V}$ greater than phosphoric acid and the limiting current is about 3\% less. However, the current does not increase as expected with the rotation rate, indicating increasing accumulation of impurities with rotation rate, which is actually a time effect. Additional samples were obtained, including a commercial one, with similar results.

\section{3. $\mathrm{C}_{2} \mathrm{~F}_{5}\left(\mathrm{C}_{6} \mathrm{~F}_{10}\right) \mathrm{SO}_{3} \mathrm{H}$}

In the previous annual report, the first sample of this acid was initially quite impure, but further attempts to purify were successful as indicated by IC (less than $0.1 \%$ ionic impurities) and by cyclic voltammetry, Fig. 11. There was a pers 'tent oxidation/adsorption in the positive potential limit which increased each time the cell was flushed, then gradually decreased with repeated scans. The hydrogen region is very well defined. RDE results are listed in Table 4 using a $0.092 \mathrm{M}$ solution saturated with oxygen. The limiting current at low rotation rates is slightly greater than that of phosphoric acid but the overpotential is also slightly greater. There is reasonable proportionality 
between limiting current and the square root of rotation rate, indicating relatively low concentraticns of impurities. Peak current for oxygen reduction in $0.089 \mathrm{M}$ acid in the TSLC was $1.85 \mathrm{~mA} \mathrm{~cm}$, at sut the same as for $0.117 \mathrm{M}$ phosphoric acid as compared in Table 2. In mixtures with phosphoric acid, the oxygen reduction peak increased only slightly in the 0.177 and $0.961 \mathrm{M}$ phosphoric acid solutions, but at $10.1 \mathrm{M}$, the addition of $2.4 \mathrm{mM}$ acid increased the peak current by about $8 \%$, see Table 3 . Since this acid foams severely, it is not usable by itself in a fuel cell.

\section{4. $\mathrm{SF}_{5} \mathrm{CHFSO}_{3} \mathrm{H}$}

Previous attempts to purify this acid were generally successful; IC analysis showed about $2 \%$ fluoride and lower concentrations of other, unidentified anions. Cyclic voltammetric peaks are very weli defined, similar to phosphoric acid, seen in Fig. 12. RDE curves are listed in Table 4 as obtained with a $0.162 \mathrm{M}$ solution saturated with oxygen. The curves were not well defined, probably due to accumulation of impurities on the electrode. In the TSLC, the peak oxygen reduction current was $1.8 \mathrm{~mA} \mathrm{~cm}^{-2}$ at an acid concentration of $0.386 \mathrm{M}$. A mixture of $0.226 \mathrm{M}$ with $9.5 \mathrm{M}$ phosphoric acid produced an increase of $26 \%$ in the peak current compared to the same concentration of phosphoric acid, Table 3.

\section{5. $\mathrm{SF}_{5} \mathrm{CF}_{2} \mathrm{SO}_{3} \mathrm{H}$}

This is the perfluorinated form of the acid in the previous paragraph. According to IC analysis, the sample contained about $2 \%$ each of fluoride and sulfate, however ít tended to decompose under the alkaline conditions required during IC. Titration with base revealed two endpoints; there was a mixture of $0.119 \mathrm{M}$ strong acid and $0.073 \mathrm{M}$ weak acid, pKa of about 7.0. The cyclic voltammogram of this mixture was well defined in the hydrogen region but the oxygen adsorption plateau was not well developed; the current rose slowly over a $0.4 \mathrm{~V}$ range, see Fig. 13. Oxygen reduction from a $0.074 \mathrm{M}$ solution at the $\mathrm{RDE}$ was quite similar to that of phosphoric acid, as listed in Table 4. Overpotential was $0.06 \mathrm{~V}$ greater than in phosphoric acid and the limiting current was essentially the same. A second sample of about $33 \mathrm{mg}$ was found not to be a mixture by titration. It was sufficient to allow a few measurements of additive effects on oxygen reduction as listed in Tables 2 and 3. In the TSLC, impurities were less of a problem than with the RDE.

\section{6. $\mathrm{SF}_{5} \mathrm{CH}_{2} \mathrm{CH}_{2} \mathrm{SO}_{3} \mathrm{H}$}

Due to decomposition in the IC column, the ionic purity of this acid was not well documented, but the sample appears to contain fluoride, chloride and possibly sulfate. Figure 14 is an IC chromatogram of this acid; similar results were obtained with the other $\mathrm{SF}_{5}$ acids. Voltammetric 
curves were however quite well defined except for excessive charge in the oxygen adsorption region, Fig. 15. In the presence of oxygen, the RDE curves of a $0.20 \mathrm{M}$ solution were unusual in that the limiting current region was curved: the current decreased with potential during the scan, again a probably sign of impurities or decomposition. Overpotential is $0.04 \mathrm{~V}$ greater and the limiting current is $10 \%$ less than phosphoric acid, according to Table 4 . Oxygen reduction in mixtures with phosphoric acid was not attempted.

\section{7. $\mathrm{SF}_{5} \mathrm{CH}_{2} \mathrm{CF}_{2} \mathrm{SO}_{3} \mathrm{H}$}

Like the preceding acid, IC analysis was complicated by decomposition under alkaline conditions; the same anions were found, but at different levels. However, after careful purification of several samples, very good cyclic voltammograms were obtained with the TSLC, as shown in Fig. 16. Even so, in the presence of oxygen the RDE curves of a $0.14 \mathrm{M}$ solution are very poor. Overpotential is $0.04 \mathrm{~V}$ greater and the limiting current is $30 \%$ less than that found with phosphoric acid, see Table 4. No further measurements were attempted.

\section{8. $\mathrm{SF}_{5} \mathrm{CHFCF}_{2} \mathrm{SO}_{3} \mathrm{H}$}

Many samples of this acid were prepared and purified, ultimately leading to quite good results. IC analysis al ways revealed fluoride, chloride and sulfate impurities in the several percent range. The well defined cyclic voltammogram of Fig. 17 was obtained after only a few cycles in the TSLC. In oxygen saturated solutions, the RDE results, Tabie 4, were quite good. Overpotential is only $0.01 \mathrm{~V}$ greater and the limiting current is only $3 \%$ less than with phosphoric acid at $400 \mathrm{rpm}$. Oxygen reduction in the TSLC was better, Table 3, and the peak current was $1.89 \mathrm{~mA} \mathrm{~cm}{ }^{-2}$, slightly higher than a similar concentration of phosphoric acid. As an additive to phosphoric acid, Table 3, increases in the peak current were noted, especially at high phosphoric acid concentrations.

\section{9. $\mathrm{C}_{4} \mathrm{~F}_{9} \mathrm{OC}_{4} \mathrm{~F}_{8} \mathrm{SO}_{3} \mathrm{H}$}

Anion analysis of this acid showed that the sample was $99.9 \%$ pure and this produced very well-defined voltammograms, but with an interesting enhancement of the desorption peak of the strongly bound hydrogen which is the prominent feature seen in $\mathrm{Fi}^{\prime}$. 18. The RDE curves were very similar to those of the reference curves of phosphoric acid. The only difference is an decrease of 0.01 $\mathrm{V}$ in the overpotential noted in Table 4 The amount available of this acid was insufficient to complete oxygen reduction studies in the TSLC, so it would merit further examination. It is highly surface active, but mav be useful as an additive. 


\section{0. $\mathrm{O}\left(\mathrm{CF}_{2} \mathrm{CF}_{2} \mathrm{SO}_{3} \mathrm{H}\right)_{2}$}

Disulfonic acids are of interest because they should be less surface active than the monosulfonic form of the same chain length. Confusing results were obtained with the first sample of this acid. IC and HPLC indicated that it was very pure and rather respectable cyclic voltammograms (Fig.19) were obtained, however with the RDE, oxygen reduction curves indicated decomposition and/or adsorption; upon scan reversal, the current quickly dropped to near zero. IRRAS was used to further investigate this and indeed a C-F band was detected on the platinum surface after scanning to positive potentials. A second sample, after careful peroxide treatment was used for oxygen reduction voltammetry in the TSLC and very normal behavior was found. Peak oxygen current was much lower than that of phosphoric acid, $1.39 \mathrm{~mA} \mathrm{~cm}^{-2}$; tests as an additive were not conducted.

\section{1. $\mathrm{CF}_{2}\left(\mathrm{OCF}_{2} \mathrm{CF}_{2} \mathrm{SO}_{3} \mathrm{H}_{2}\right.$}

Titration of the first sample of this acid with base showed a second inflection due to the presence of a weak acid impurity and IC showed a considerable concentration of fluoride, about $20 \%$. Cyclic voltammograms were the worst of the series, with many extraneous peaks. As with the previous ether-containing acid, the RDE curves in the presence of oxygen indicated that a surface film was formed which essentially shut down the further reduction of oxygen. Recently, a second sample was synthesized and purified with much better results, as can be seen in the cyclic voltammogram of Fig. 20. RDE measurements were not repeated, rather oxygen reduction in the TSLC was chosen. Peak currents in oxygen saturated solutions were low compared to phosphoric acid, only $1.54 \mathrm{~mA}$ $\mathrm{cm}^{-2}$. As an additive to phosphoric acid there was little enhancement, only about $4 \%$ when added to the most dilute phosphoric acid solution and no effect with the other concentrations, as listed in Table 3. This is surprising since the combination of a diether linkage with a disulfonic acid suggests good oxygen solubility.

\section{2. $\left(\mathrm{CF}_{3} \mathrm{SO}_{2}\right)_{2} \mathrm{CH}_{2}$}

The benefit of using this unusual acid in the reduction of oxygen have already been noted(2); there is an enhancement of oxygen solubility and and a decrease of overpotential. The sample used in that initial study was prepared in Dr. Gard's laboratory. An additional sample was prepared for ionfirmation. Unfortunately, it was not of exceptionally purity, as shown by IC analysis, several per cent of halides, and cyclic voltammetry, Fig. 21. Even so, the RDE curves, shown in Fig. 22 do indicate a noticeable improvement in both solubility and overpotential at low rpm where the effect of impurities is small. In the TSLC, the impurities were less of a problem and the peak oxygen reduction current was $2.56 \mathrm{~mA} \mathrm{~cm}^{-2}$, the highest of this group of acids and the overpotential was the smallest. As an additive to phosphoric acid, the increase in peak current ranged from $4 \%$ to $29 \%$ at 
the concentrations listed in Table 3.

\section{3. $\mathrm{CF}_{3} \mathrm{SO}_{3} \mathrm{H}$}

A commercial sample of this acid was obtained from Johnson- Matthey as a straw-yellow liquid. After treatment with hydrogen peroxide, it became water clear. IC and HPLC tests were not conducted. The cyclic voltammogram, Fig. 23, suggests no serious impurities. Oxygen peak currents in the TSLC were $2.27 \mathrm{~mA} \mathrm{~cm}^{-2}$ at a concentration of $0.101 \mathrm{M}$, which would suggest the possibility of additive effects. However, the data in Table 3 show no measureable increases at the concentrations used.

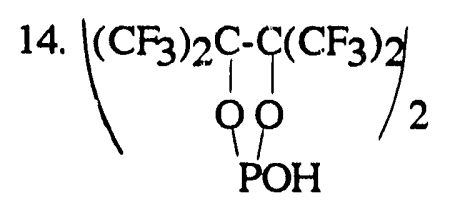

A small sample of this curious, bicyclic acid was briefly evaluated. At saturation, the concentration is about $0.01 \mathrm{M}$. Cyclic curves, given in Fig. 24 are very reasonable in view of the lack of peroxide treatment. Oxygen peak currents in the TSLC were $1.56 \mathrm{~mA} \mathrm{~cm}^{-2}$, but the peak potential was only $0.55 \mathrm{~V}$ vs. RHE, which indicates considerable inhibition of the kinetics of reduction. No further evaluations were attempted.

\section{Infrared Reflectance-Absorption Spectroscopy (IRRAS)}

The thin solution layer cell (TSLC) for IRRAS measurements of adsorbed species on the surface of a platinum electrode is shown in Fig. 25; the design is substantially the same as was used with a laser source (5). The cell was attached to a beam deflector with adjustable incident angle control, designed in conjuction with the Herrick Co., and mounted in the cell compartment of a Nicholet 20DX FTIR. The working electrode was a platinum disk polished to a 0.05 micron alumina finish. The reference and counter electrodes were externally located in the solution inlet and outlet tubes. The first spectra obtained were of $\mathrm{CO}$ adsorbed on $\mathrm{Pt}$ in a $\mathrm{HClO} 4$ solution which is a well-documented system (6).

The next system investigated was the decomposition/adsorption of the diacid ether, $\mathrm{O}\left(\mathrm{CF}_{2} \mathrm{CF}_{2} \mathrm{SO}_{3} \mathrm{H}\right)_{2}$, which was suggested by the $\mathrm{RDE}$ measurements. Here a small signal was obtained in the C-F region (1350-1100 $\mathrm{cm}^{-1}$ ) after application of potentials greater than $1 \mathrm{~V}$ (RHE). The peak is see in Fig. 26 at $1250 \mathrm{~cm}^{-1}$. This difference spectrum was obtained by first recording a reference spectrum at $0.15 \mathrm{~V}$, increasing the potential, recording a second spectrum and the difference 
is given in the figure. The development of this peak strongly suggests that a compound with a C-F bond(s) is adsorbed on the electrode surface. This was a very encouraging result and shows the usefulness of IRRAS in the search for adsorbed acids that may create the "dry hole" at the electrode solution interface discussed earlier. However, while this system was being investigated, the FTIR spectrometer failed. Because repair cust were in excess of funds available, the instrument was not in service for thie rest of the project. It is anticipated that the repairs will be made after the start of the next fiscal year.

\subsection{Conclusions}

The objectives identified at the start of this three year grant have, to a large extent been realized over the two year period that it was funded. That is, twelve fluorosulfonic acids have been systhesized, purified and evaluated by electrochemical techniques that allow promising acids to be identified for fuel cell applications. Additionally, chromatographic techniques have been shown to be of great value in the monitoring the purity of the acids.

Organic impurities, in all cases, can be effectively removed by boiling the acids with excess hydrogen peroxide. The addition of $30 \%$ hydrogen peroxide in the amount of 10 to $20 \%$ by volume is sufficient. The temperature should be at the boiling point for several hours to effect oxidation. Then a large piece of platinum gauze is added and boiling is continued until no further gas evolution is evident; this will take several hours. The acid concentration is determined by titration with base. HPLC with spectrophotonetric detection at $245 \mathrm{~nm}$ was used to follow the oxidative clean-up, and when the chromatogram showed no peaks, the resulting cyclic voltammogram was well-developed in terms of hydrogen and oxygen adsorption/desorption. The next step in future purifications would be the removal of inorganic species. Fluoride, chloride and sulfate were generally found by IC in the acids. Some samples were freed of these anions by sublimination or by recrystallization. A much better technique would be ion exchange. Some progress was made to develop a procedure, but lack of time prevented its completion. The possible deleterious effects of, especially, chloride will not be known until samples are prepared that are free of ionic impurities. It has been shown that IC is an excellent method to monitor low concentrations of anions in these acids. In spite of this incompleted aspect of the project, oxygen reduction results of interest were obtained.

The quantities of the acids obtained were sufficient to prepare about 10 to $25 \mathrm{~mL}$ of about $0.1 \mathrm{M}$ solutions in most cases. Significient results relating to the relative properties of these acids in the reduction of oxygen are summarized in Tables 2, 3, and 4. Several acids allowed a noticeable decrease in the overpotential for reduction and several also had increased solubility for oxygen. Since impurities were still present and could accumulate on the electrode surface, the use of a low volume cell helped to avoid their effect, and thereby reveal the intrinsic behavior of the acids. In a fuel cell at high temperature, impuritiss are gradually oxidized and/or adsorbed on the high surface area 
of the cathode ( and anode). Therefore the use of the TSLC is justified. Restricting the evaluation to low concentrations is not realistic. However, those acids that show any improvement over phosphoric acid can be identified and then synthetic efforts can be focussed on them. At this time, it does not appear likely that any of these acids have the high solubility in water to allow operation at typical fuel cell temperatures of $180^{\circ} \mathrm{C}$. Solubilities were not determined quantitatively in all cases, so there may be exceptions to this statement. It was decided that an efficient use of the remaining time allowed for this project would be to determine additive/synergistic effects of these acids on phosphoric acid. Since the acids are all thermally stable to temperatures in excess of $180^{\circ} \mathrm{C}$, some benefit might be found in mixtures that could improve fuel cell performance. Additive effects are increases in oxygen concentration in proportion to the added acid, measure by the peak current in a linear potential scan of oxygen reduction. Synergistic effects would be superproportional to the concentration of the added acid, or a decrease in the overpotential for oxygen reduction.

Of the seven acids tested as additives, six showed additive effects with low concentrations of phosphoric acid and of these, four showed synergistic effects when added to $10.1 \mathrm{M}$ phosphoric acid (Table 3). These preliminary results were obtained at room temperature with surprisingly low concentrations of added acids; clearly it will be necessary to extend the measurements to temperatures and concentrations used with fuel cells to establish the benefits suggested at this time. Incidentally, measurements with $85 \%$ phosphoric acid could not be included because of the lack of supplies. These results with mixtures of acids are the most significant findings of this project and should serve as a guide in the planning of any further research in the use of fluorosulfonic acids in fuel cells. 


\subsection{References}

1. D. Ferrier, K. Kinoshita and P. Stonehart, J. Electroanal. Chem. 61, 233 (1975)

2. H. Saffarian, P. Ross, F.E. Behr and G. L. Gard, J. Electrochem. Soc. 137, 65

3. M. Razaq, A. Razaq and E. Yeager, Gas Research Institute Final Report, July 1987.

4. M. Razaq, A. Razaq, E. Yeager, D. D. DesMarteau, S. Singh, J. Electro. Chem.

Soc. 136 , 385 (1989).

5. D. K. Roe, J. K. Sass, D.S. Bethune and A. C. Luntz, J. Electroanal. Chem., 216 , 293 (1987).

6. J. K. Sass, D. K. Roe, D. S. Bethune and A. C. Luntz, Ber. Bunsenges. Phys. Chem., 91, 320 (1987). 


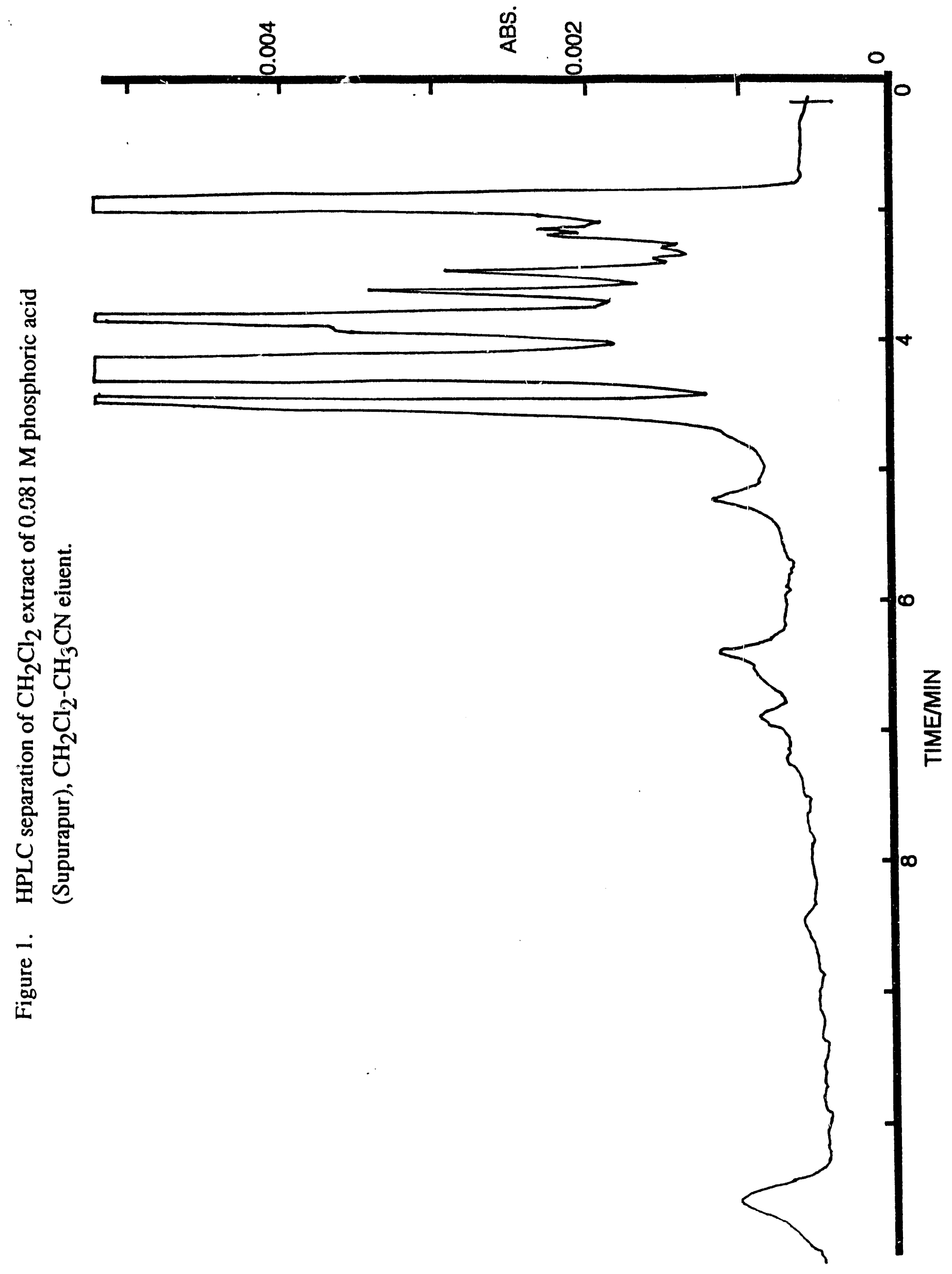




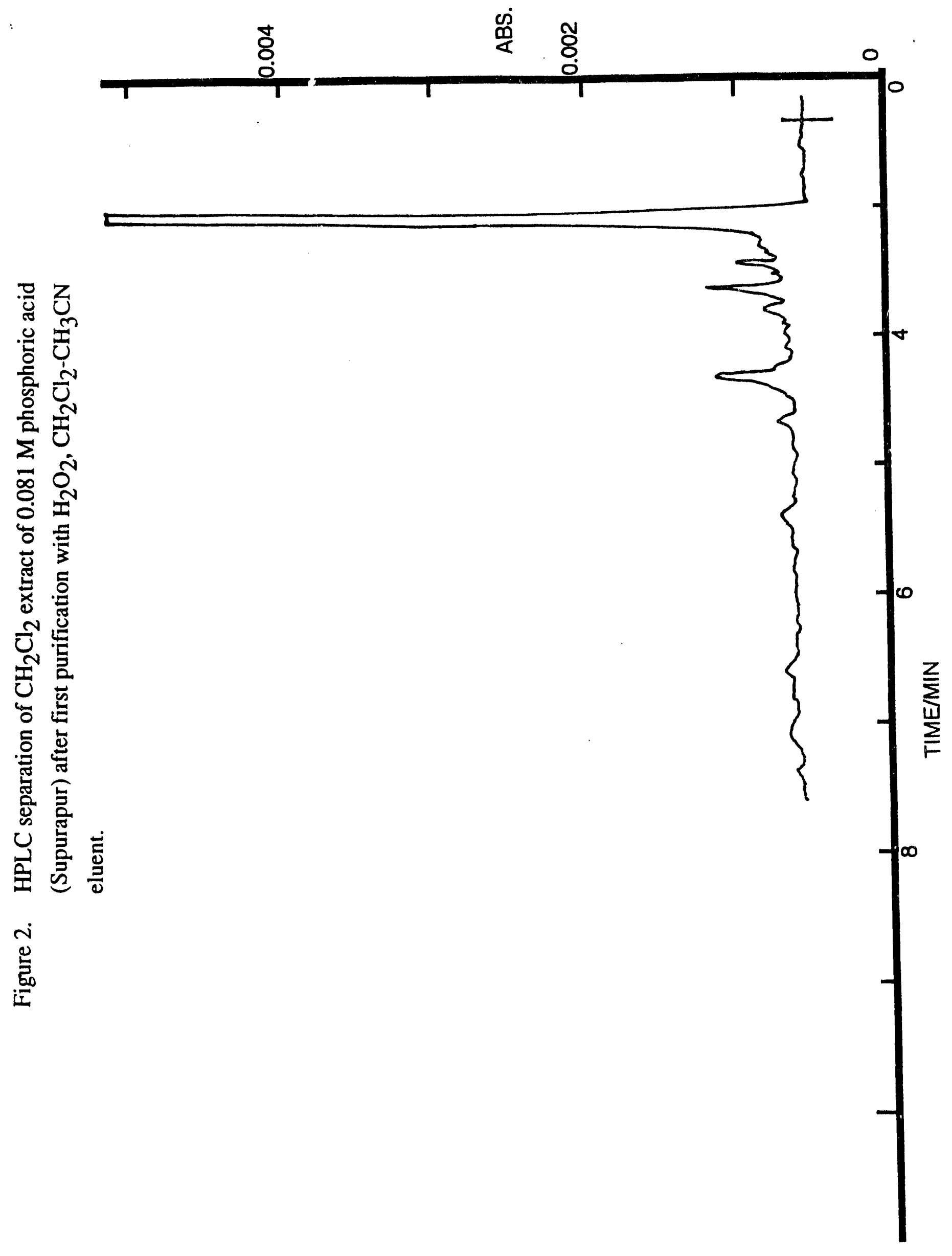


Figure3. Ion chromatogram of $0.081 \mathrm{M}$ phosphoric acid, carbonate-bicarbonate eluent.

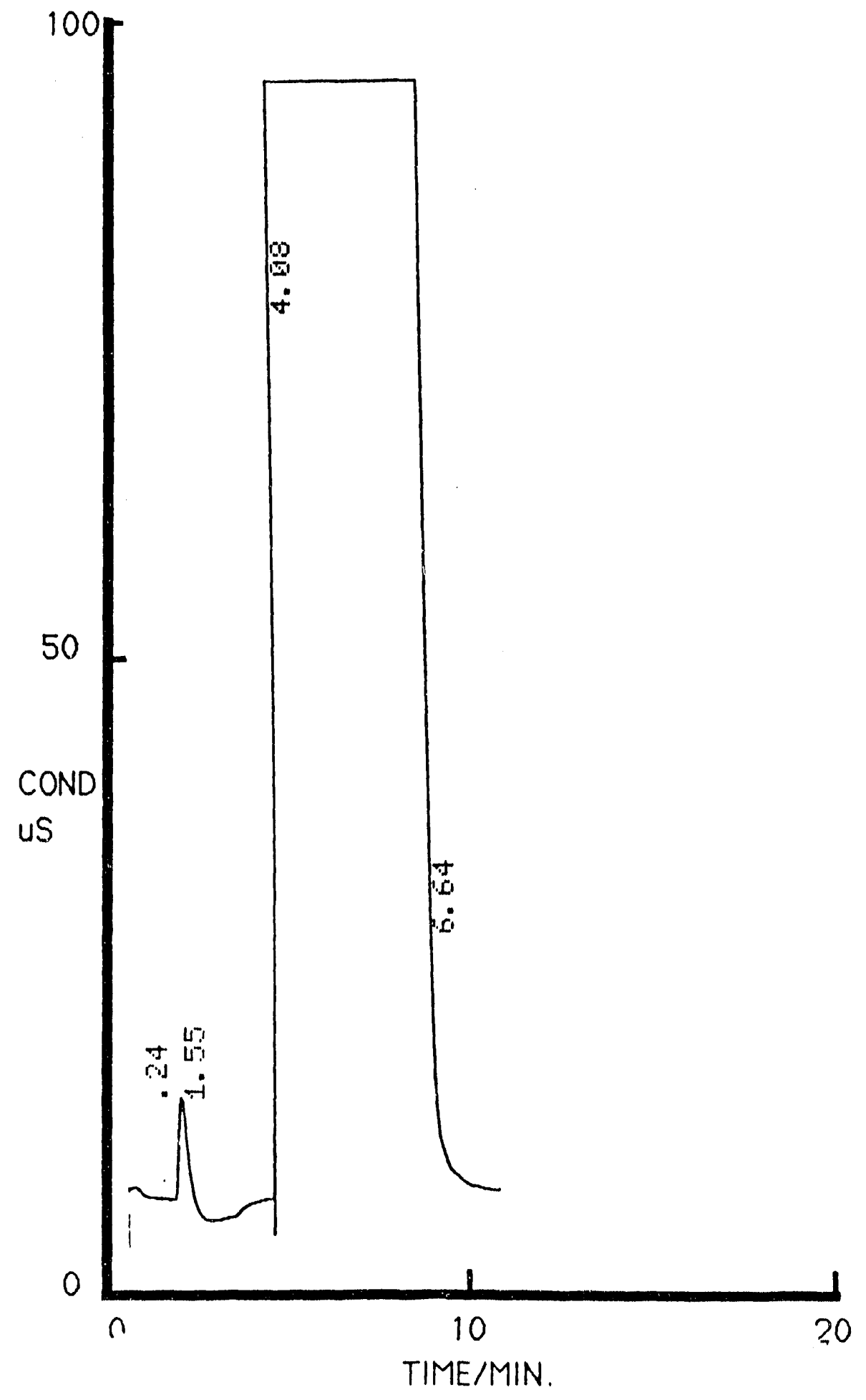



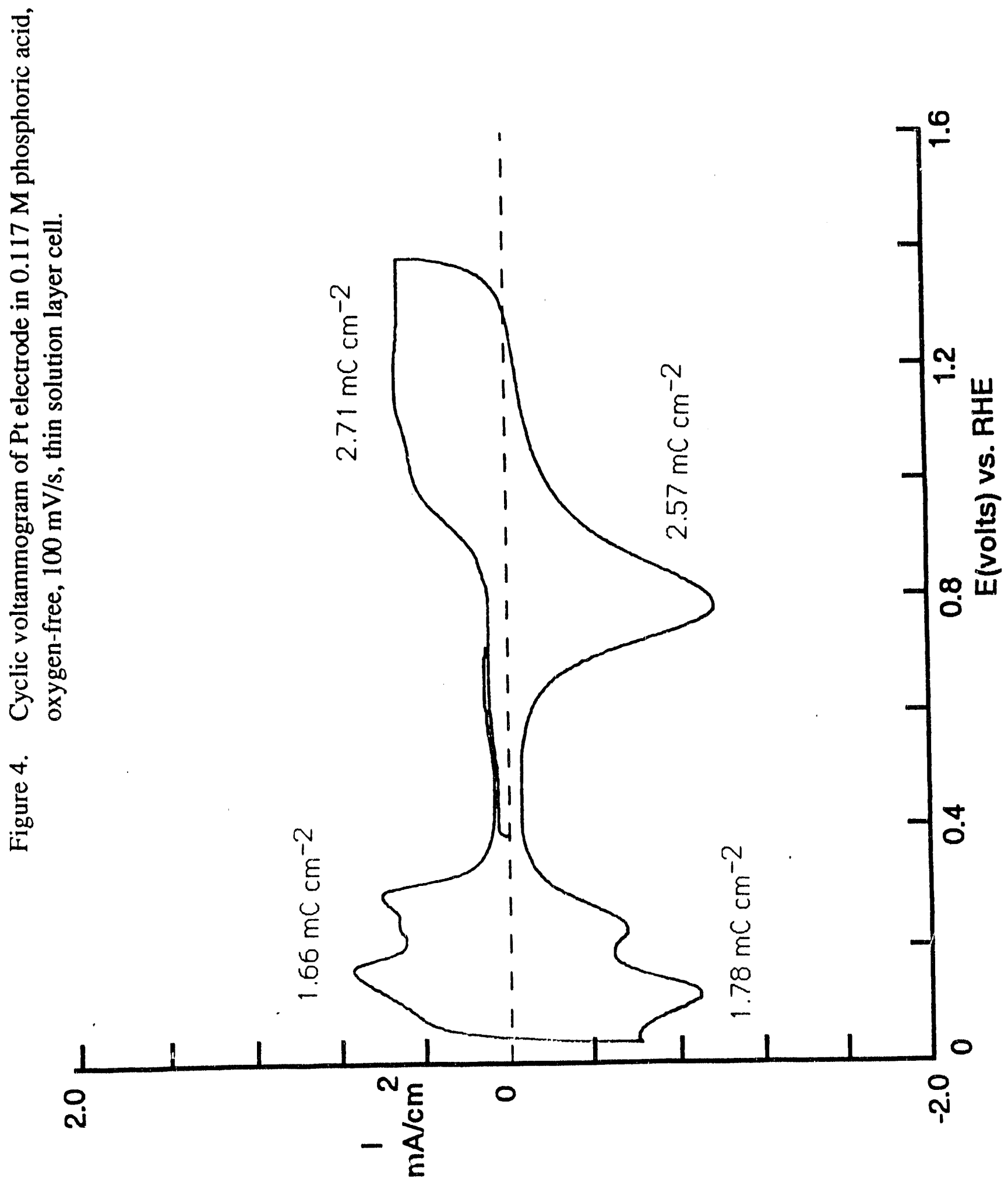

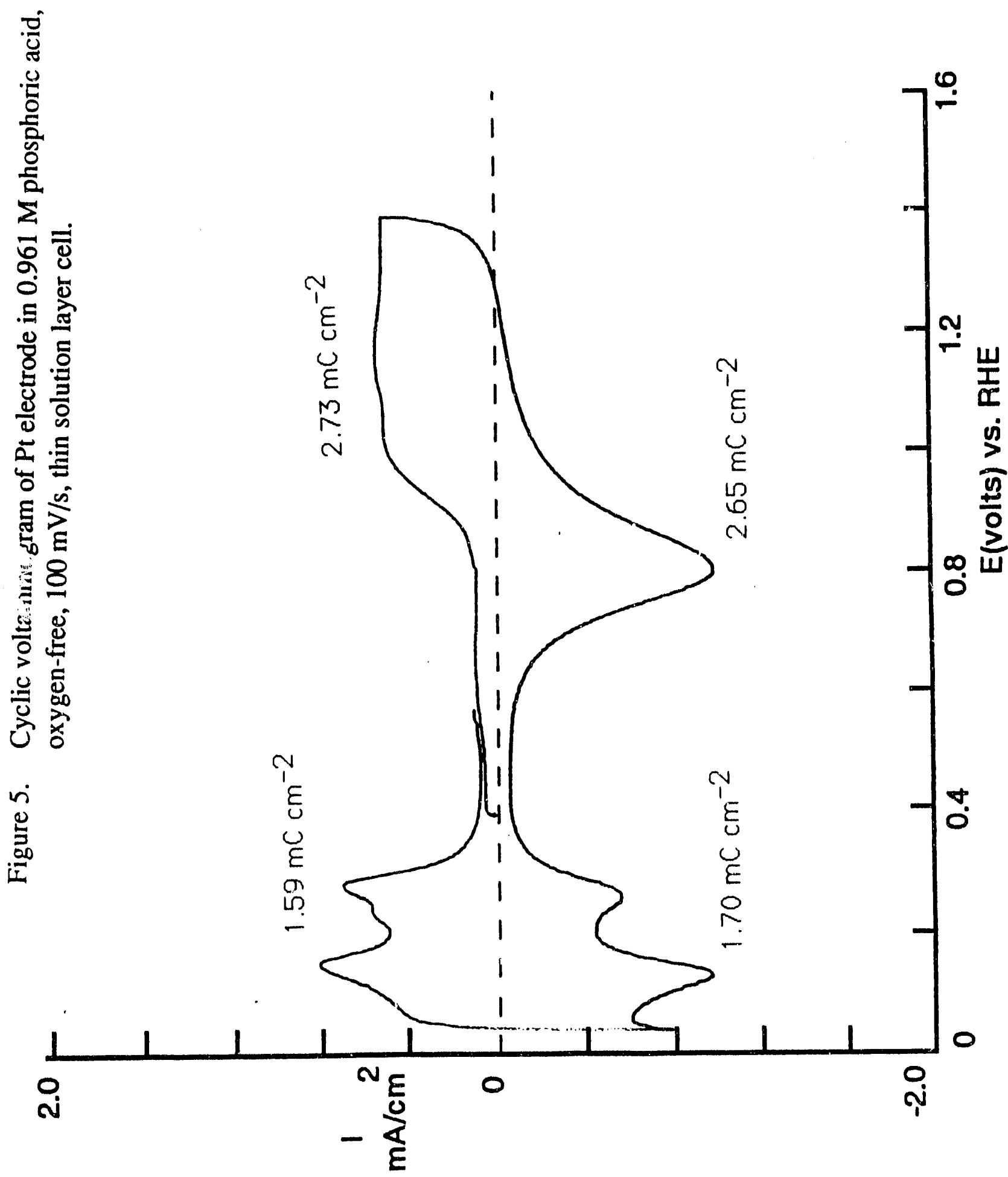


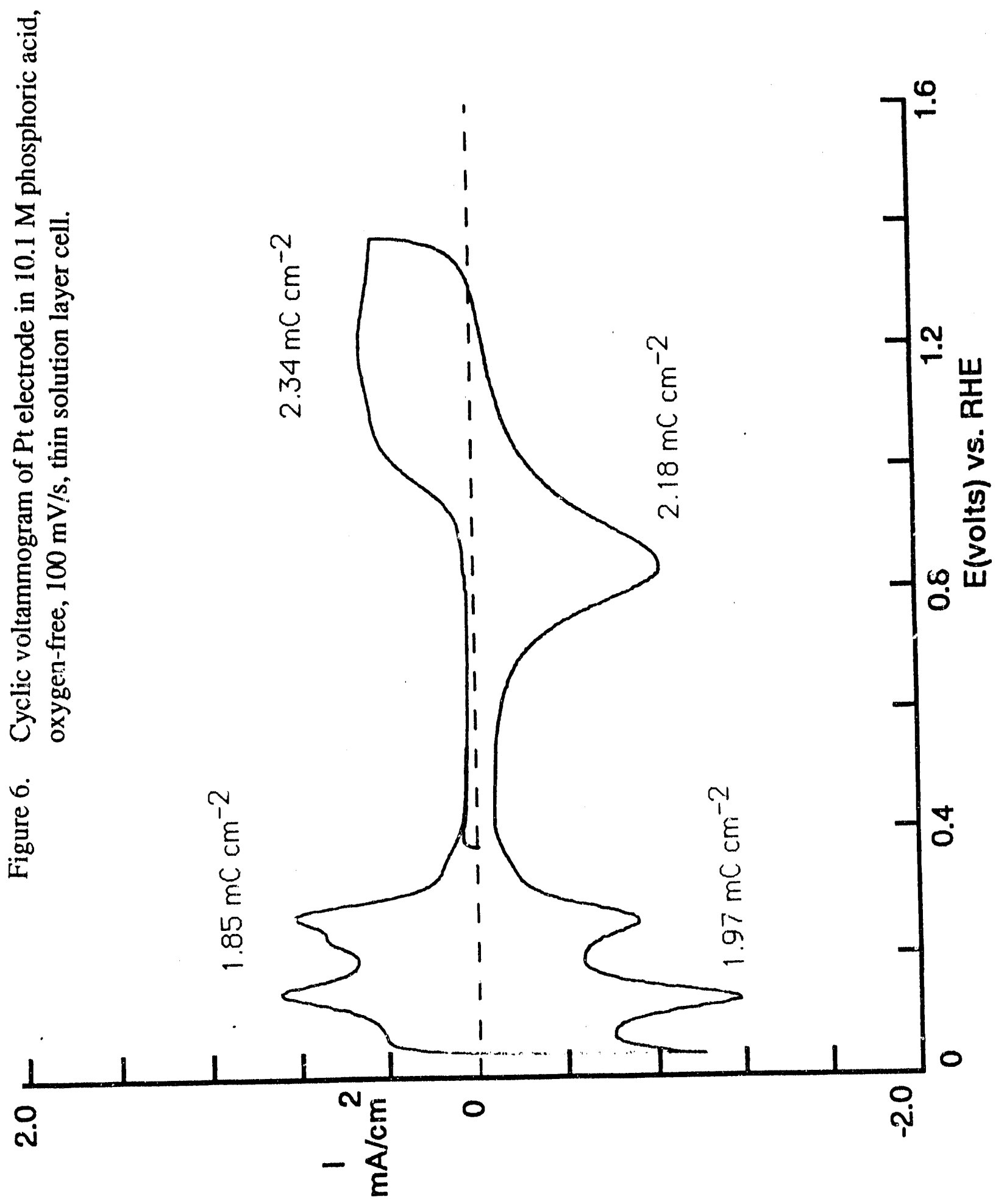



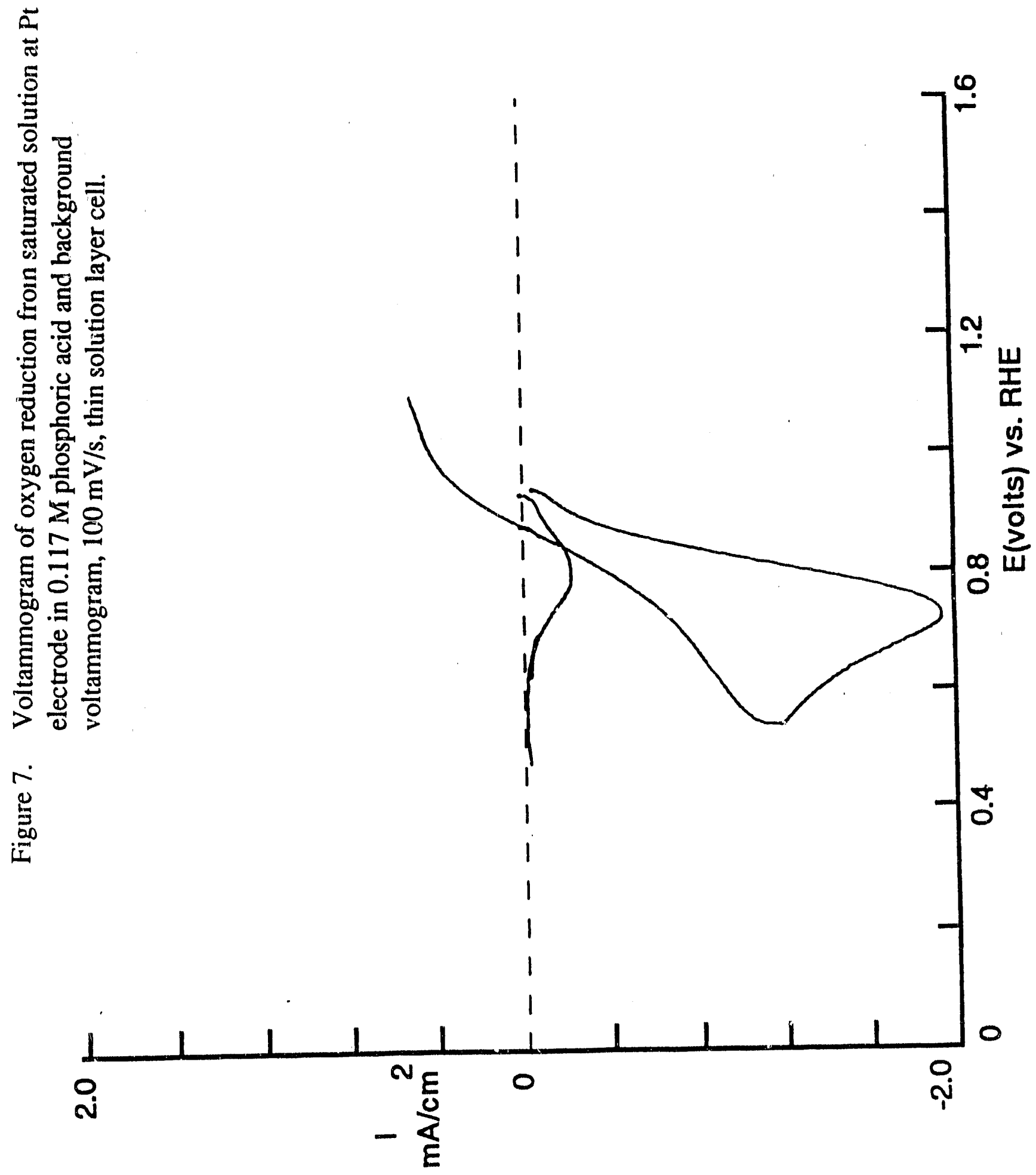

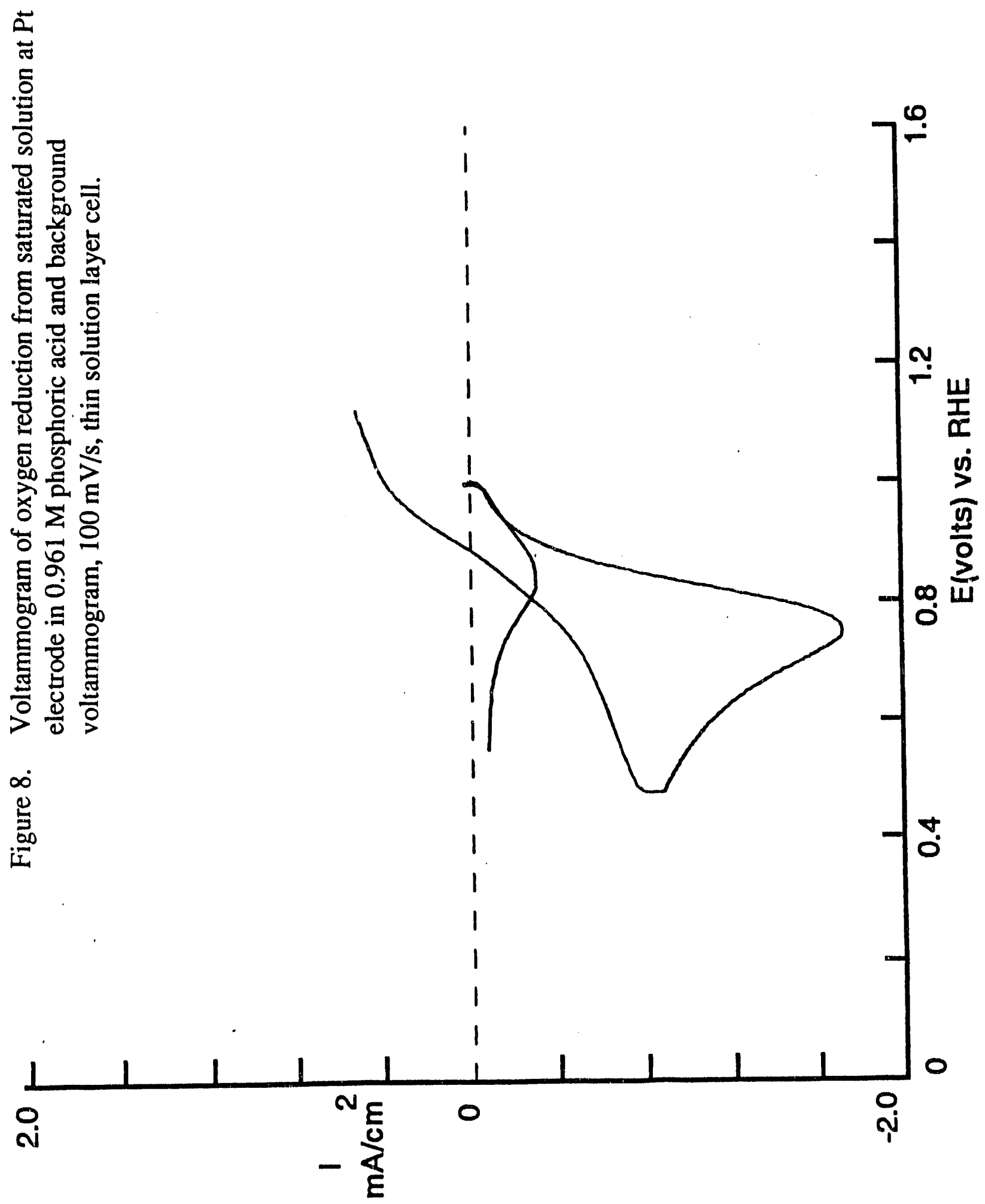

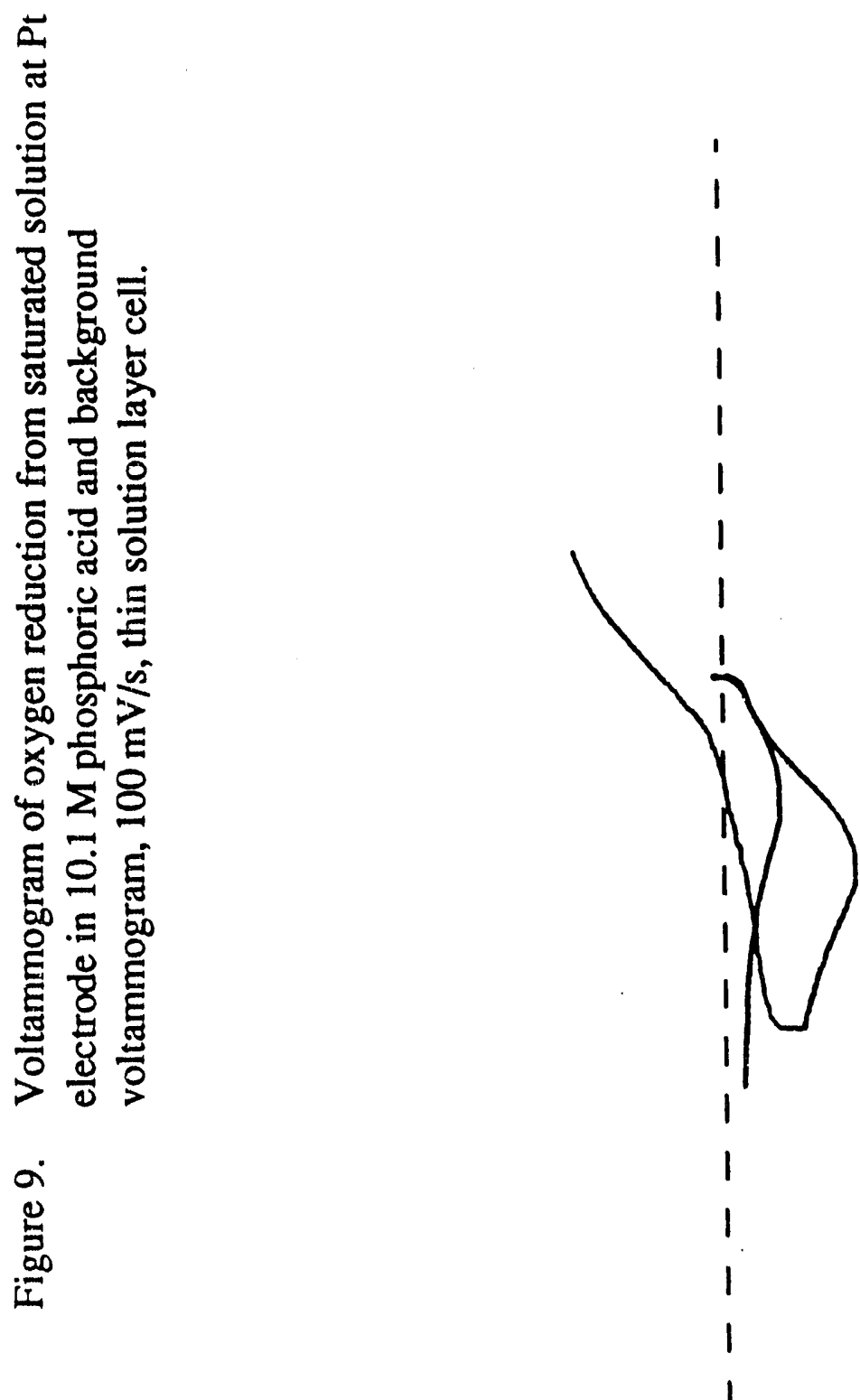

]$^{\infty}$

$\frac{4}{a}$

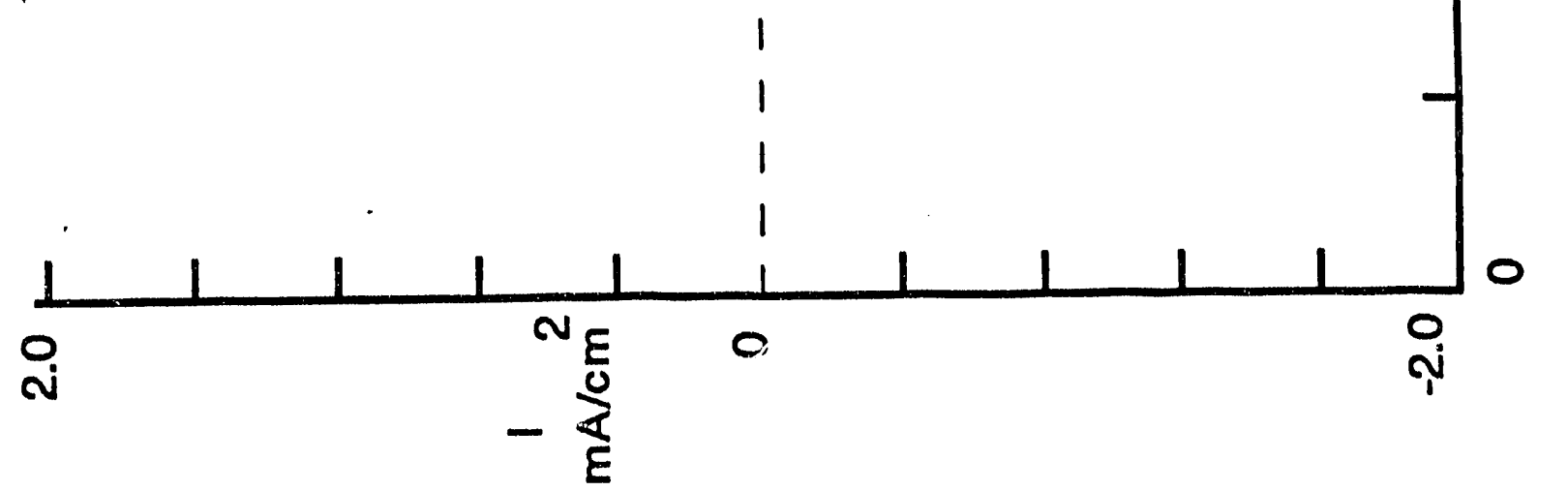




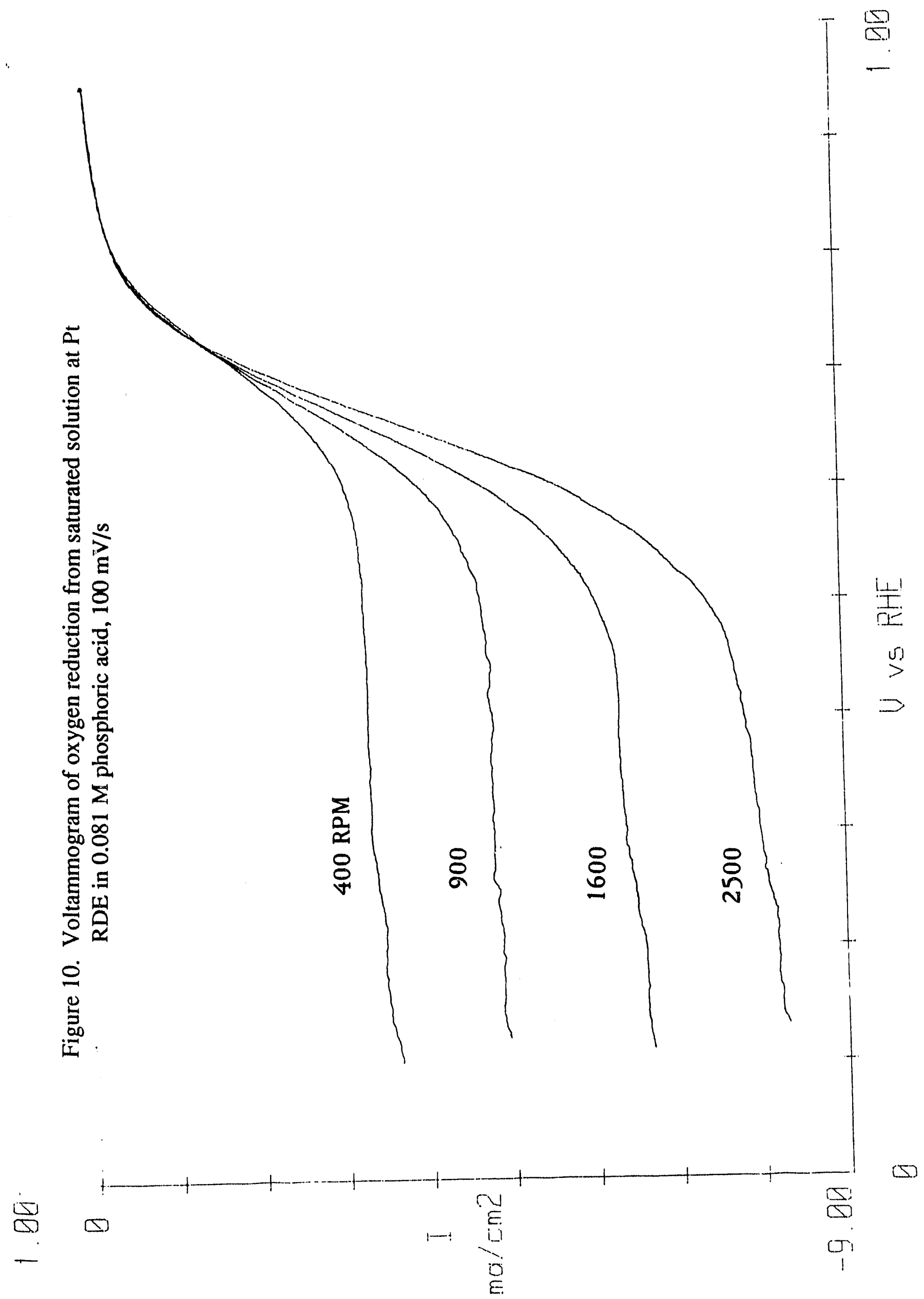




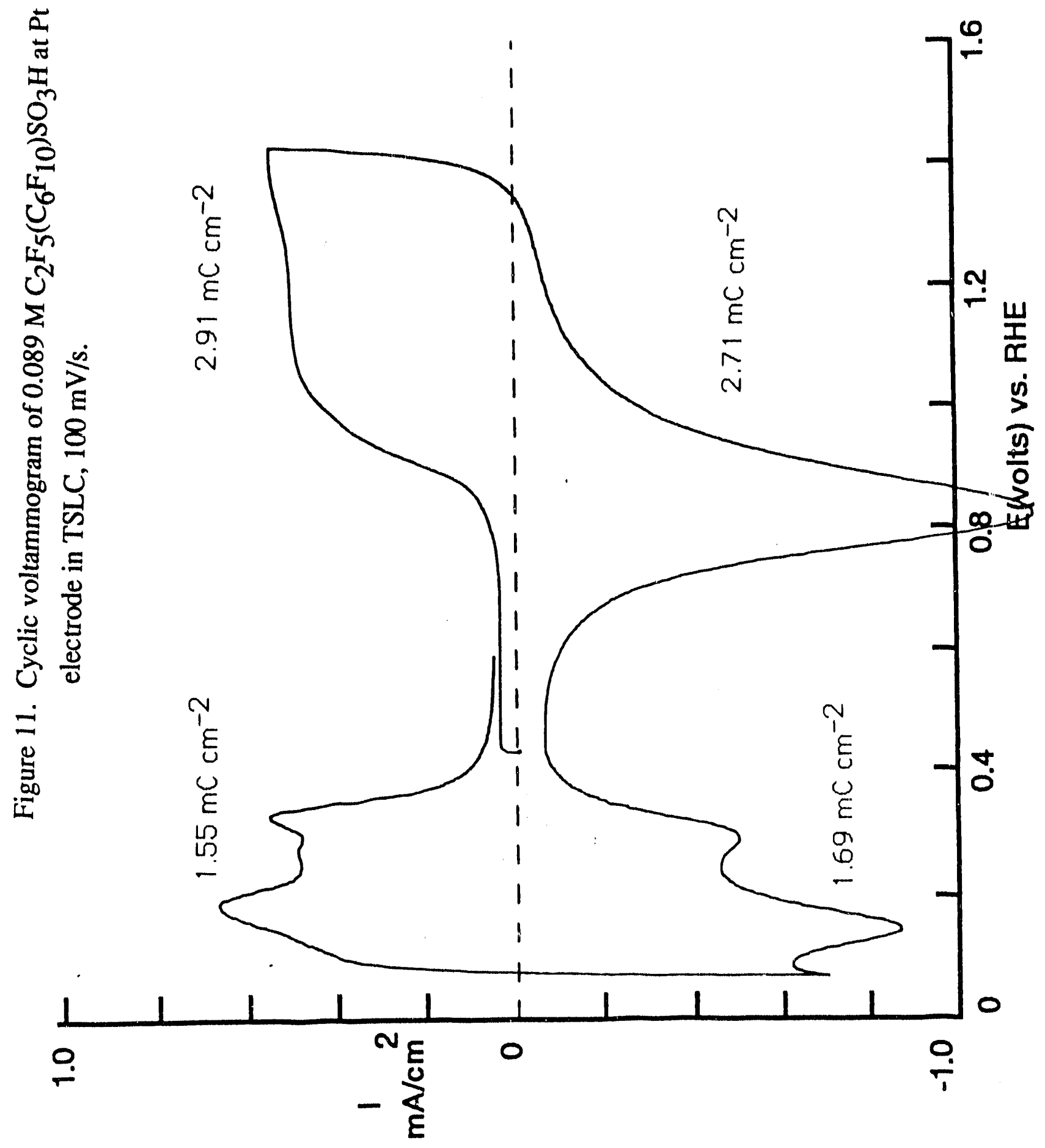



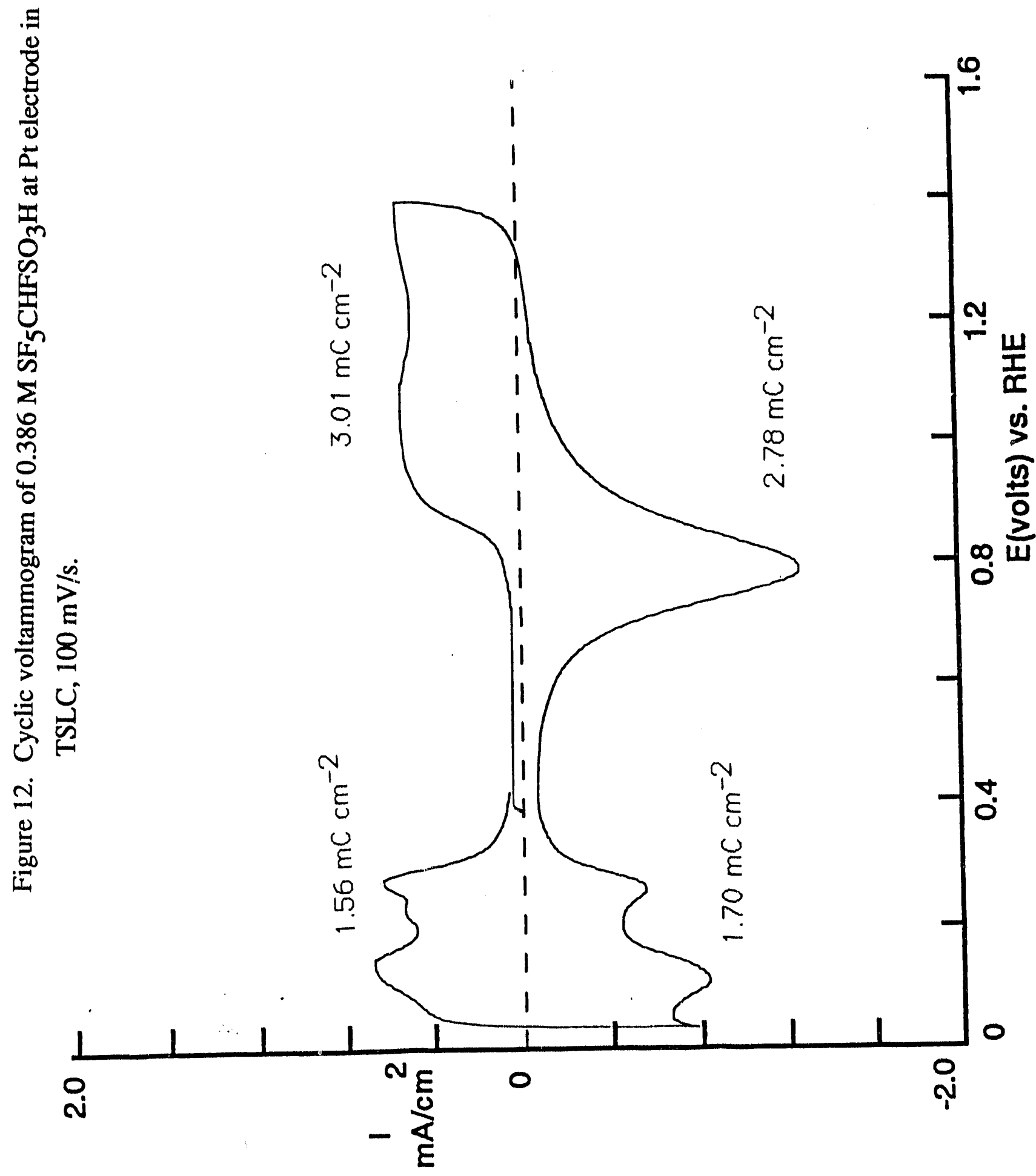


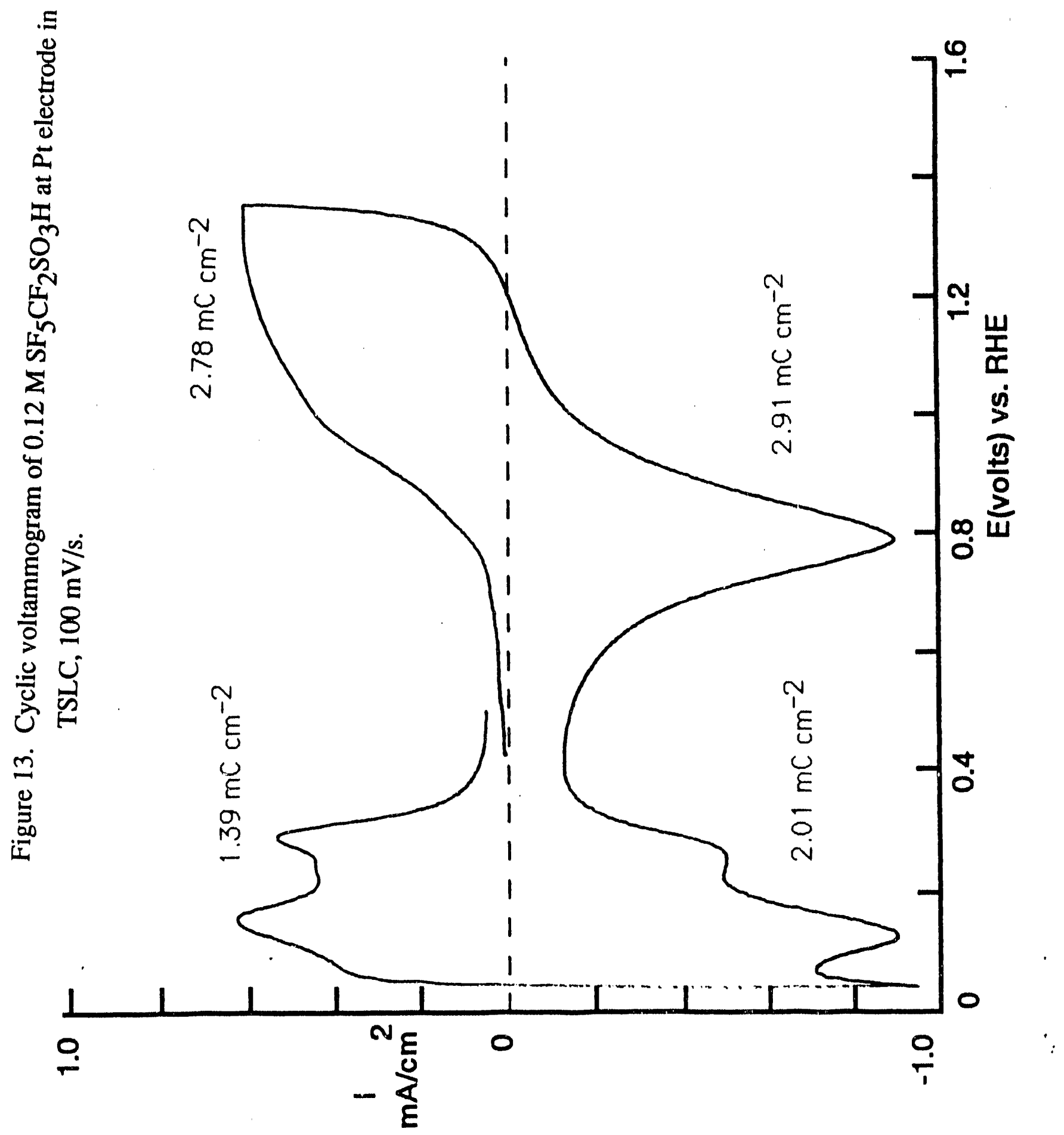


Figure 14. Ion chromatogram of $0.02 \mathrm{M} \mathrm{SF}_{5} \mathrm{CH}_{2} \mathrm{CH}_{2} \mathrm{SO}_{3} \mathrm{H}$, carbonate-bicarbonate eluent.

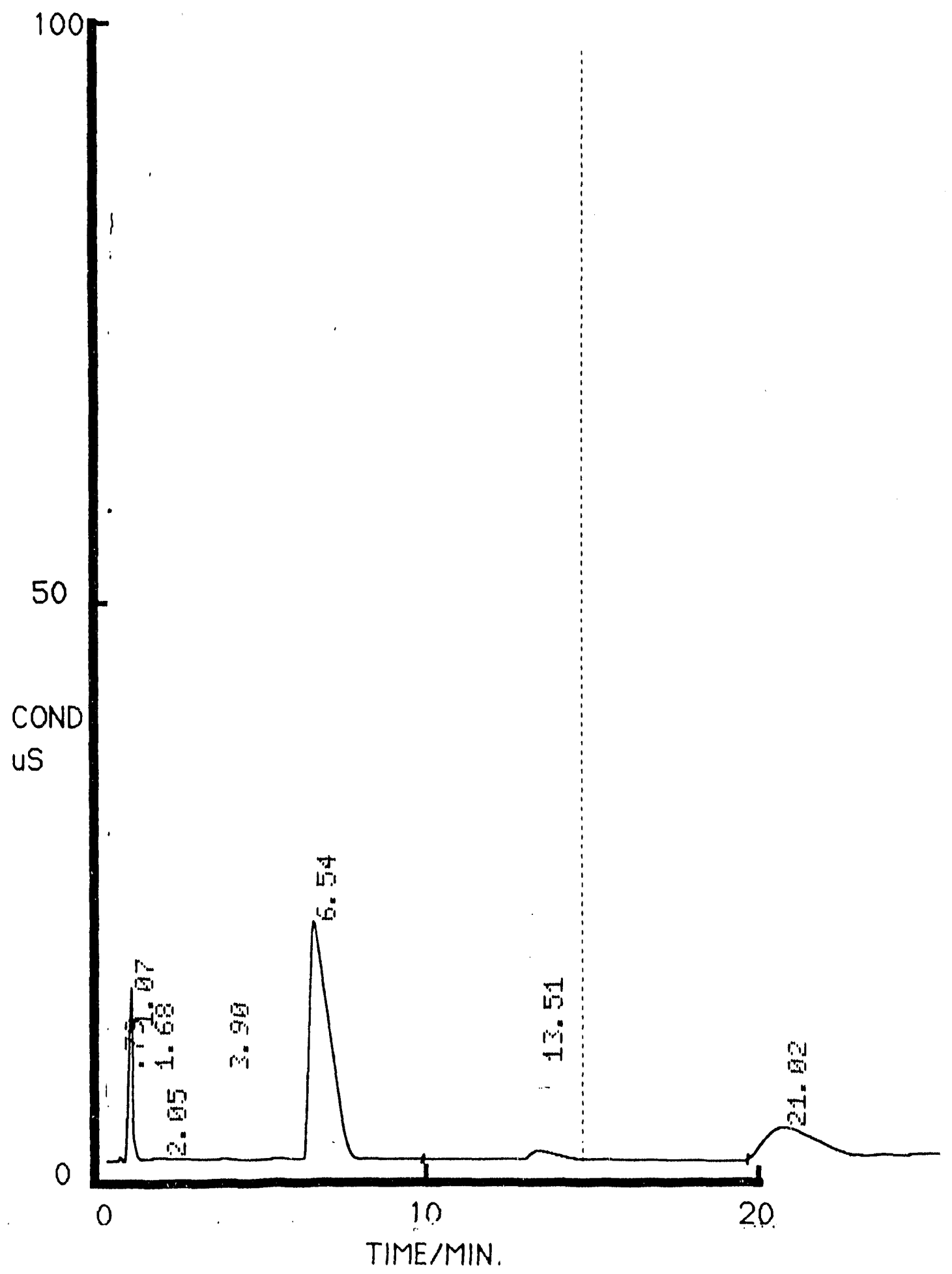




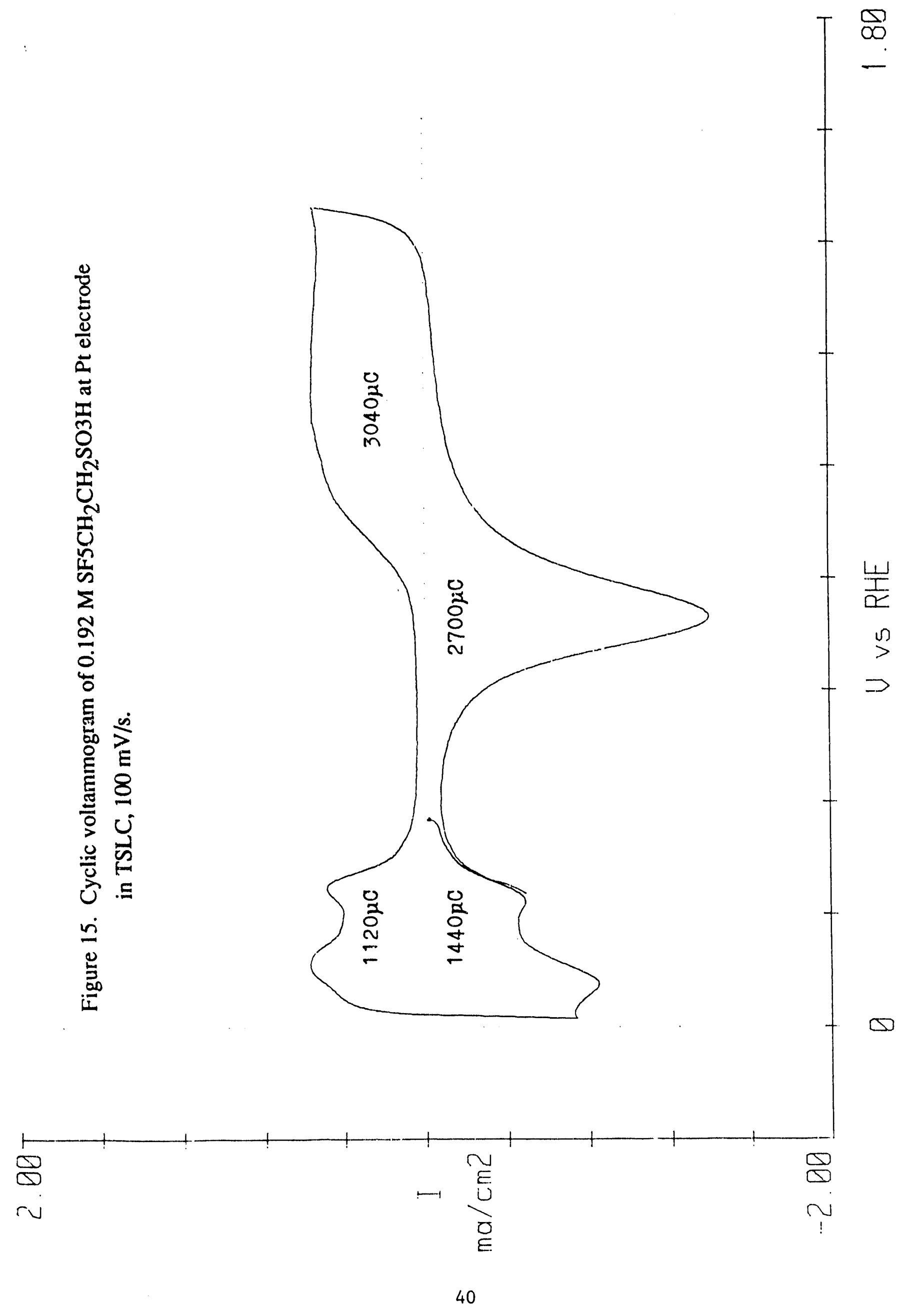




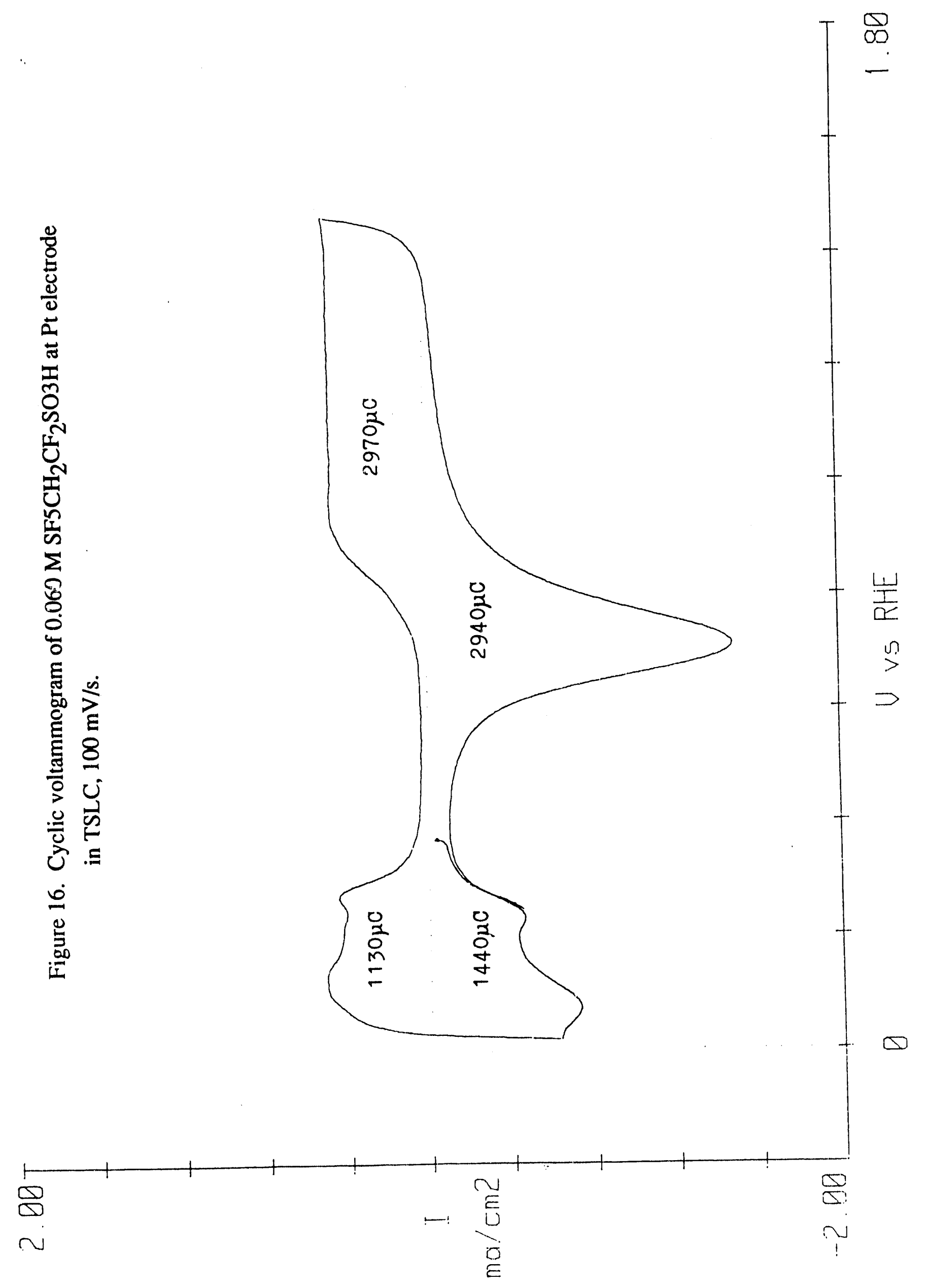




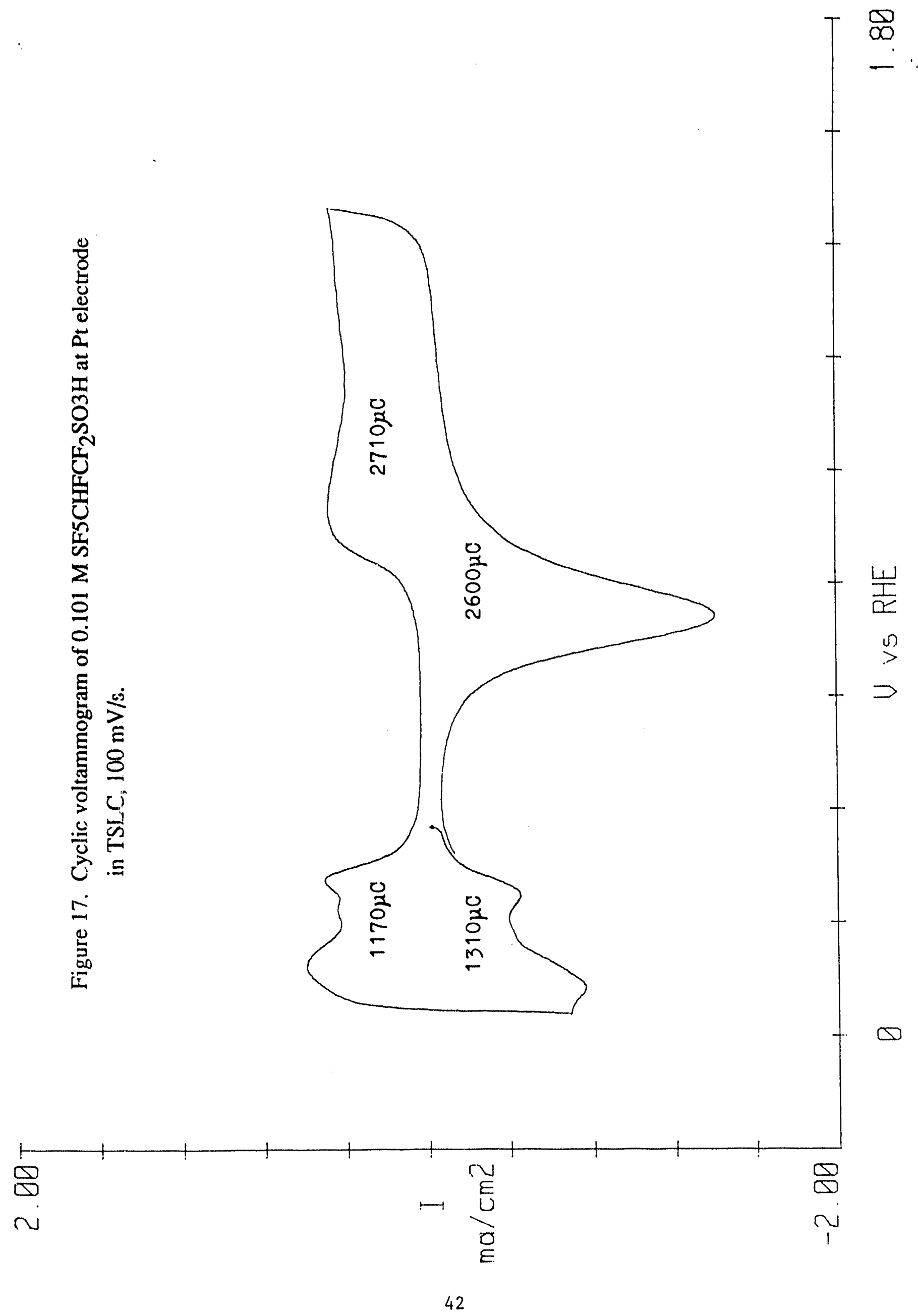




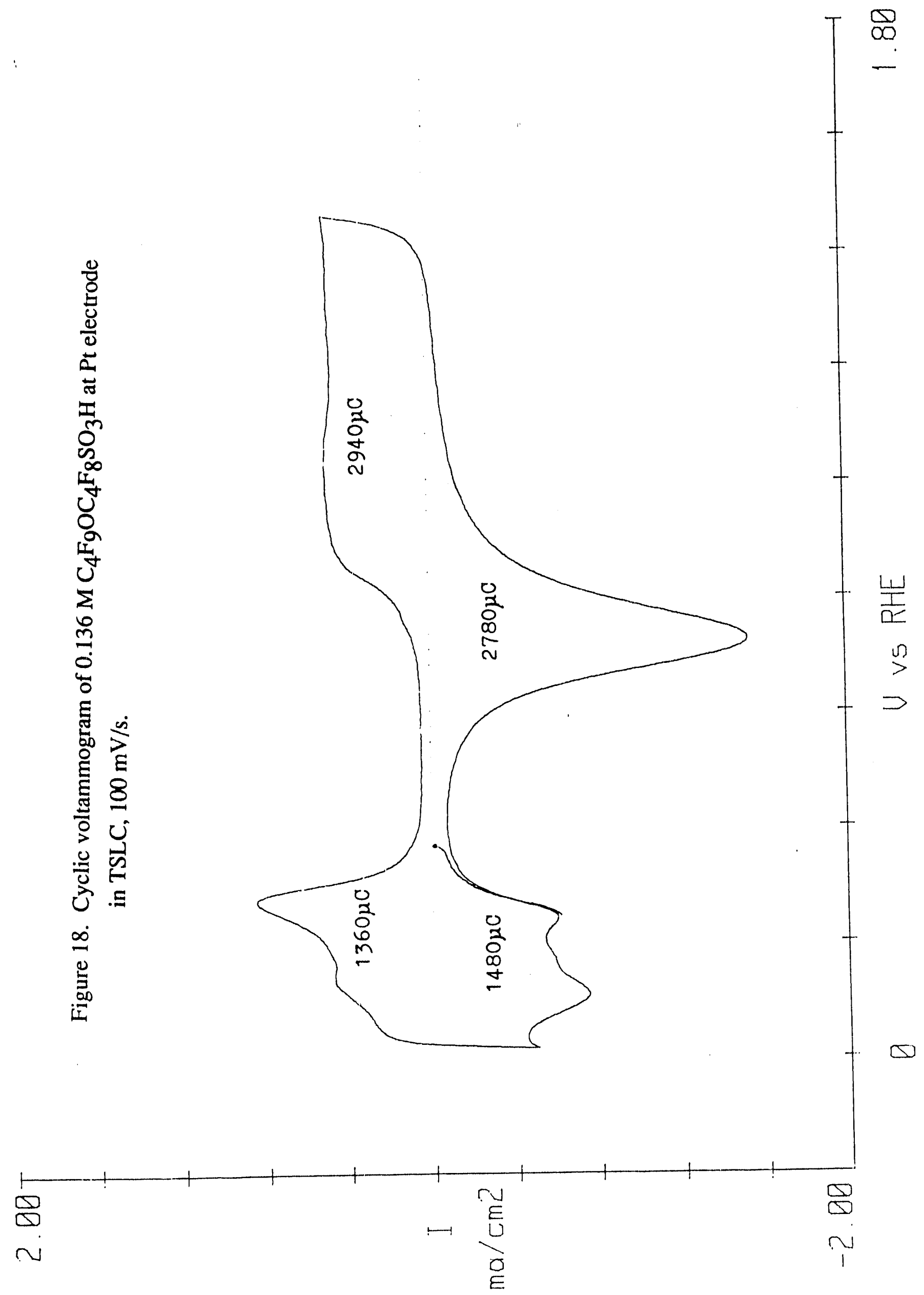




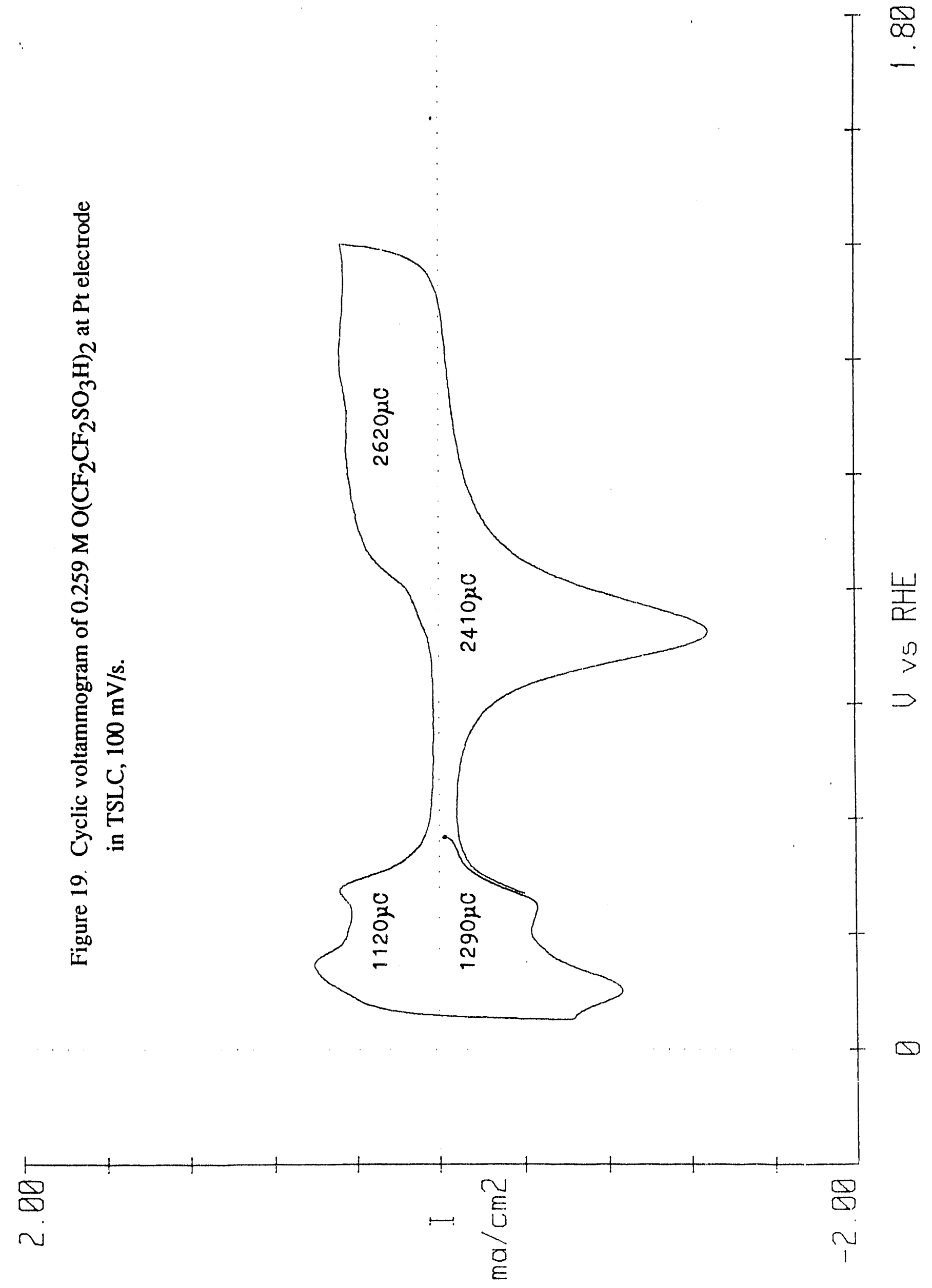



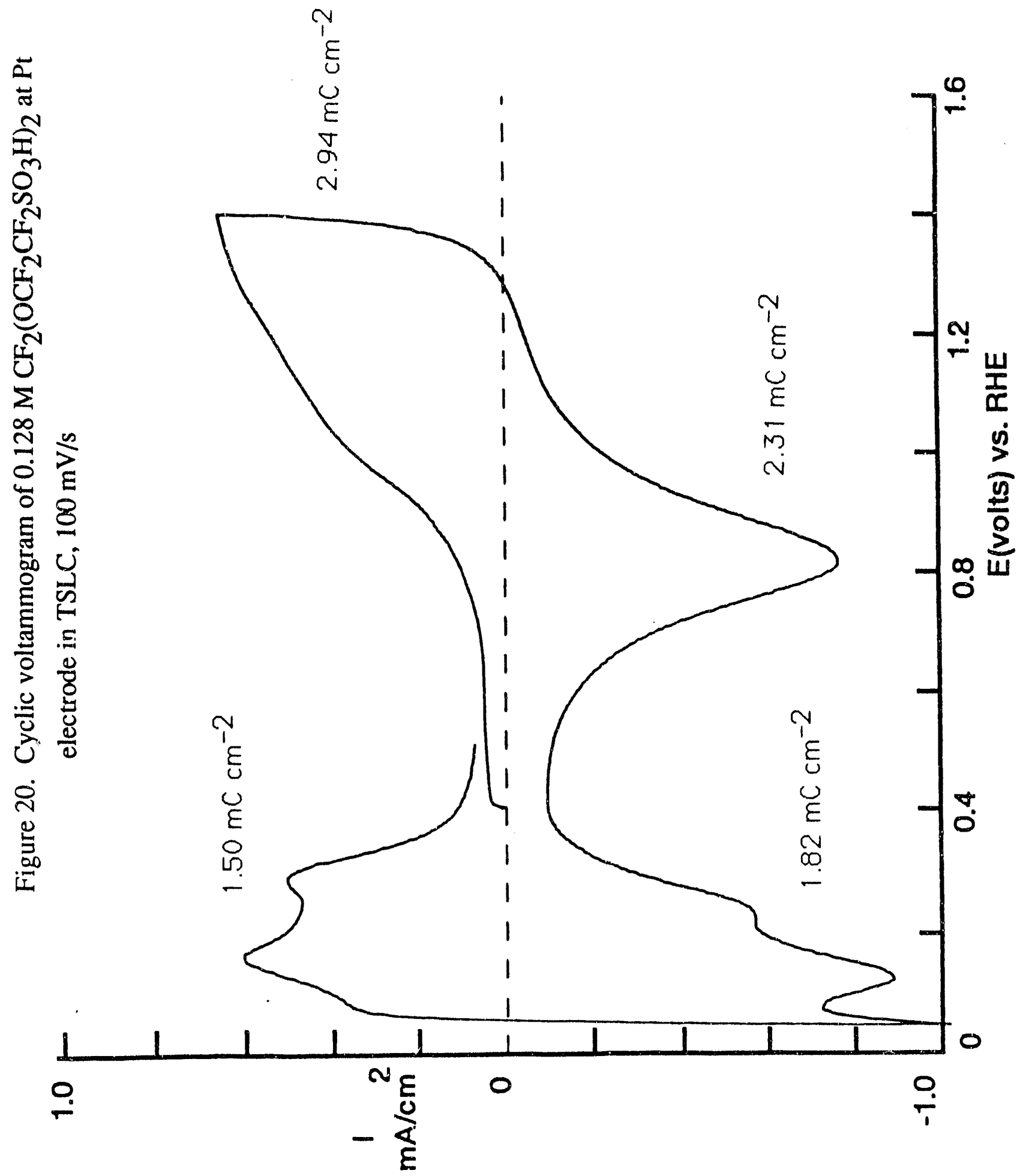


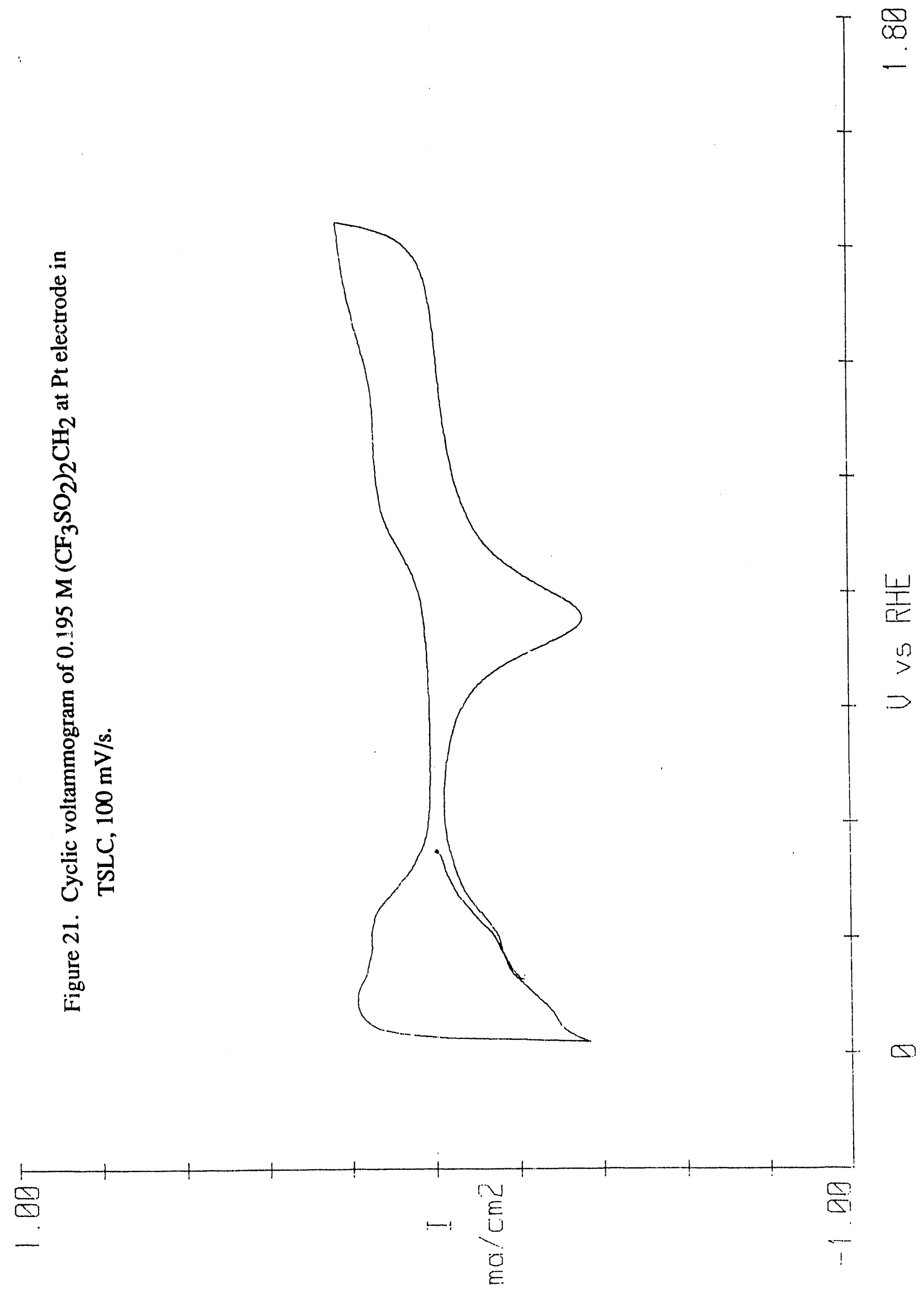



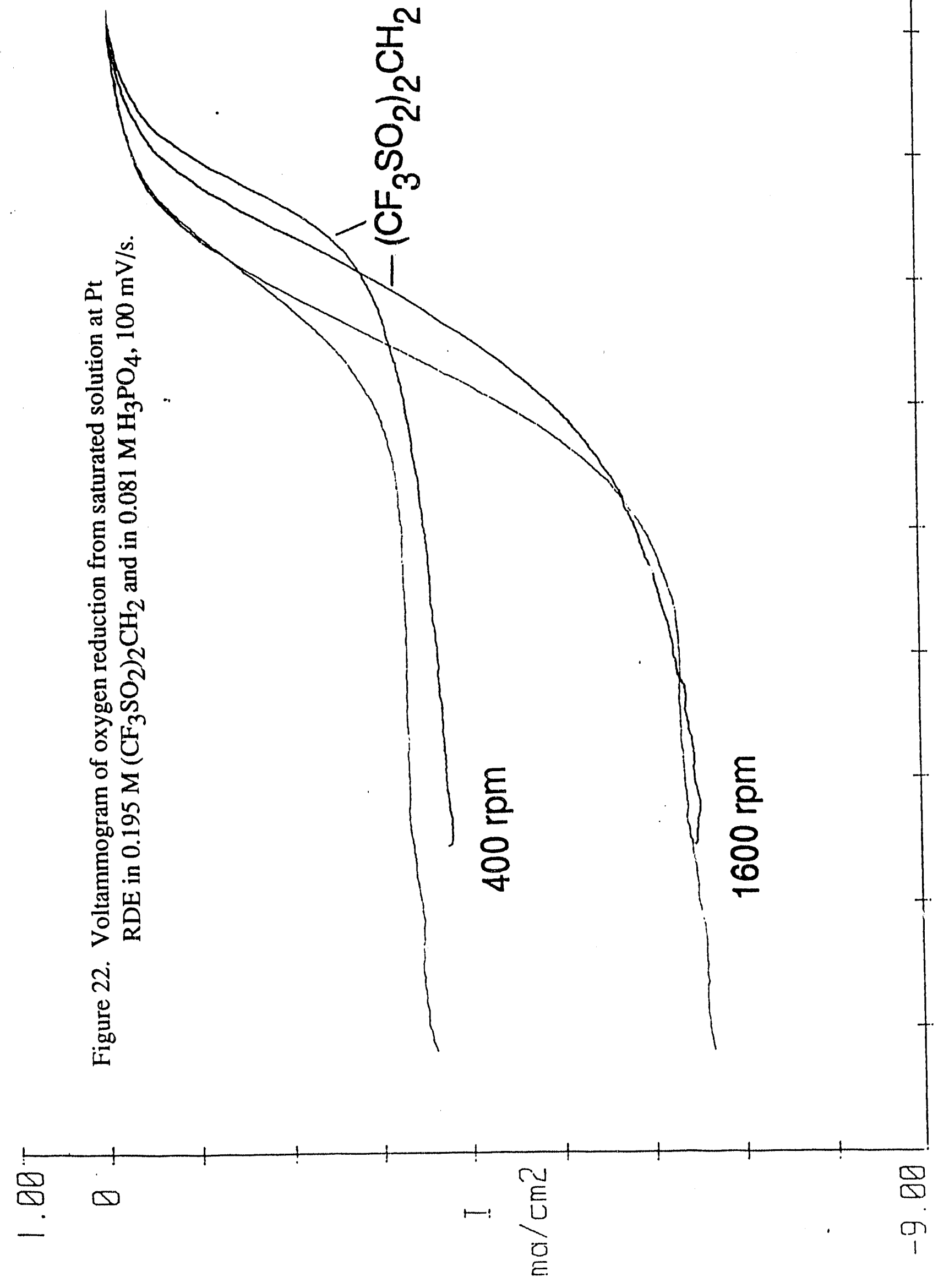

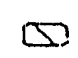



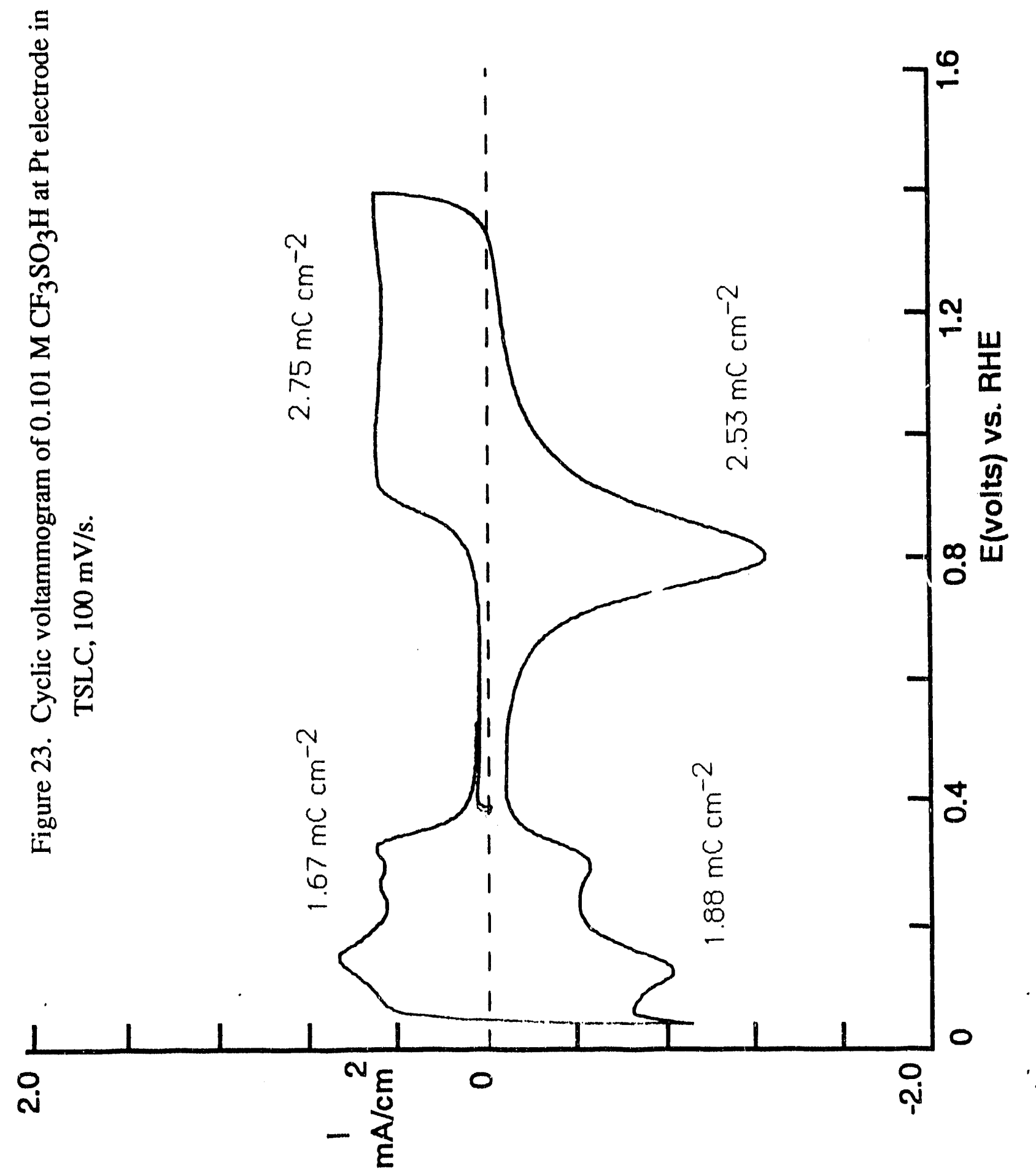


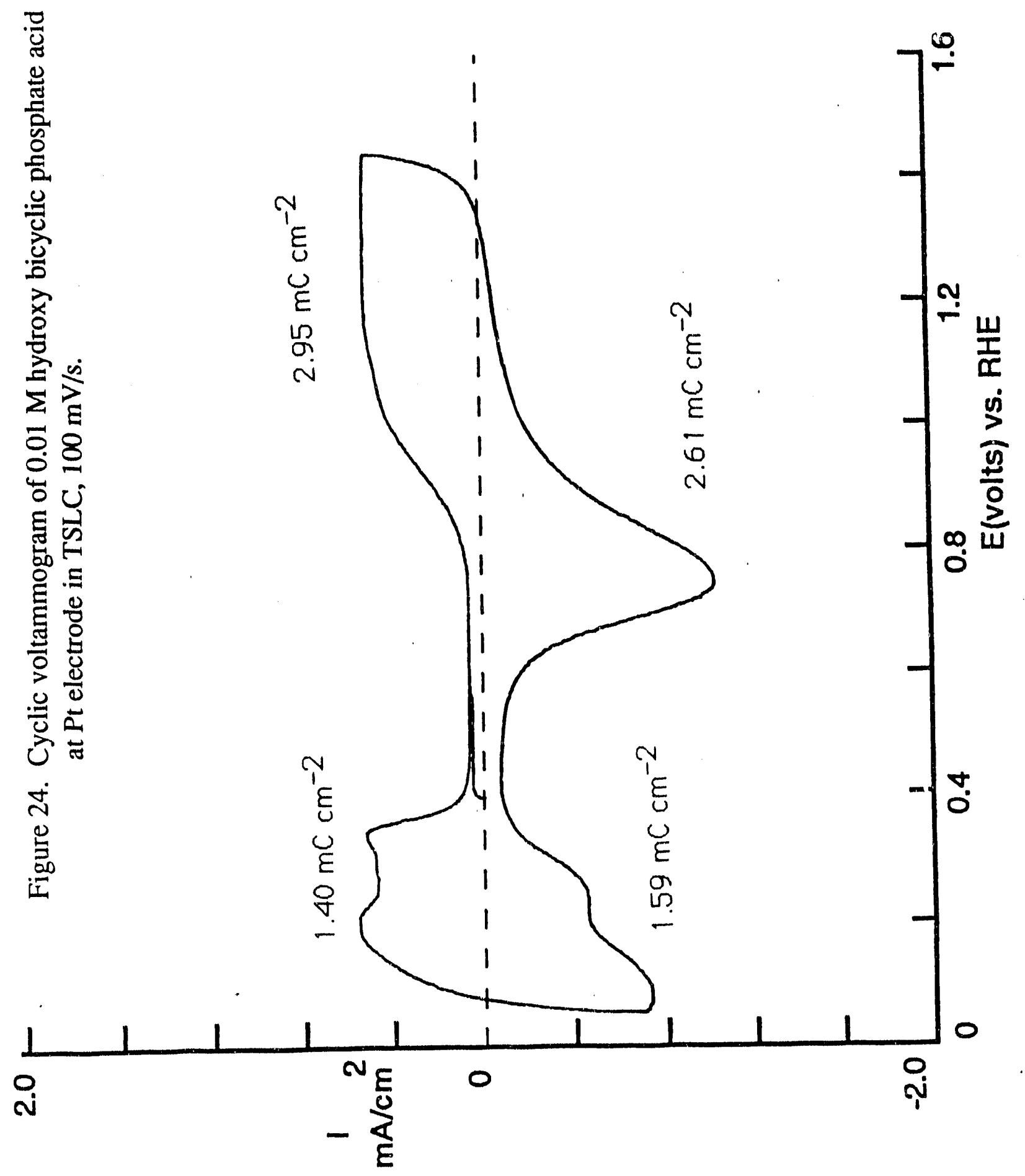




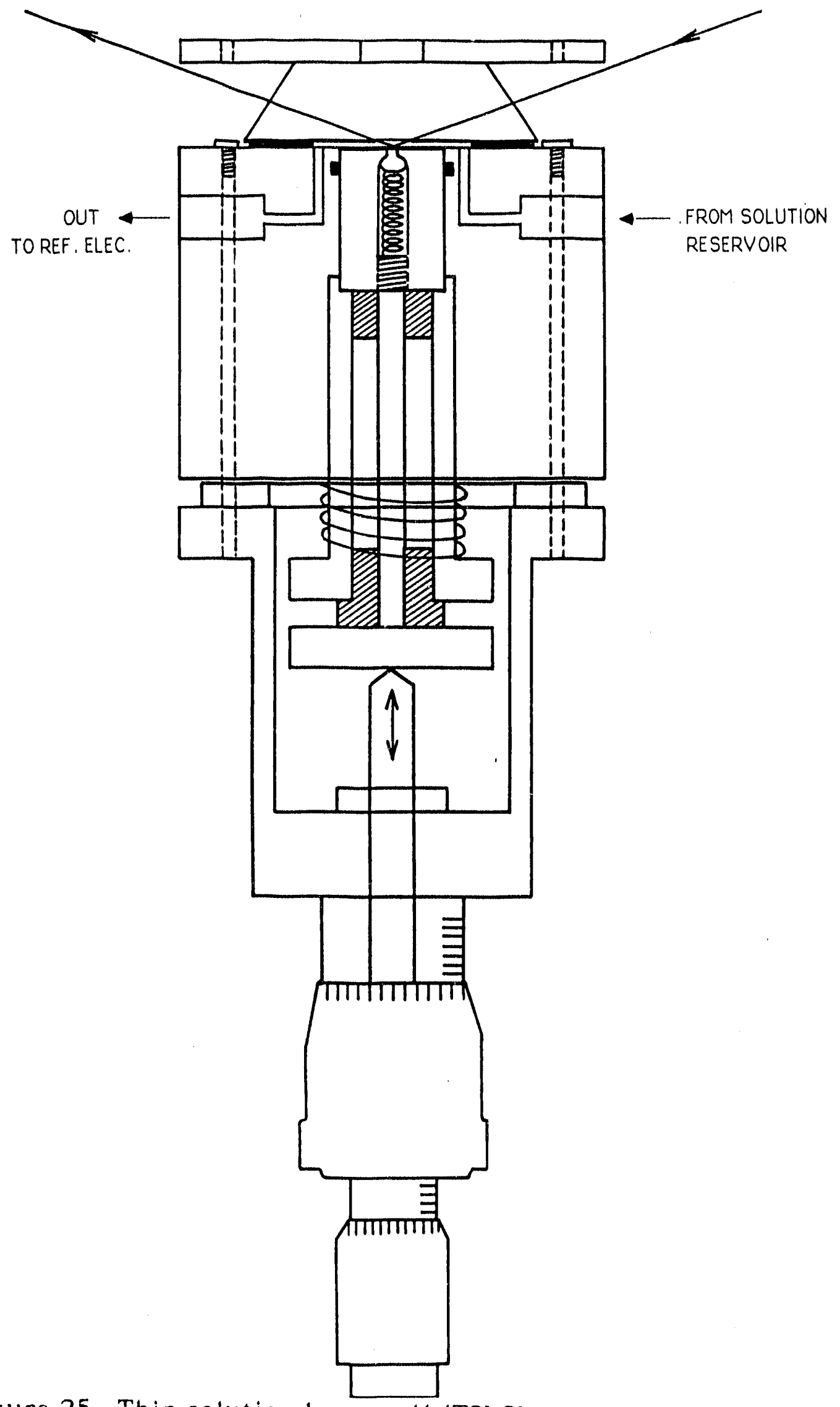

Figure 25. Thin solution layer cell (TSLC) for IR reflectance spectroscopy and cyclic voltammetry. 


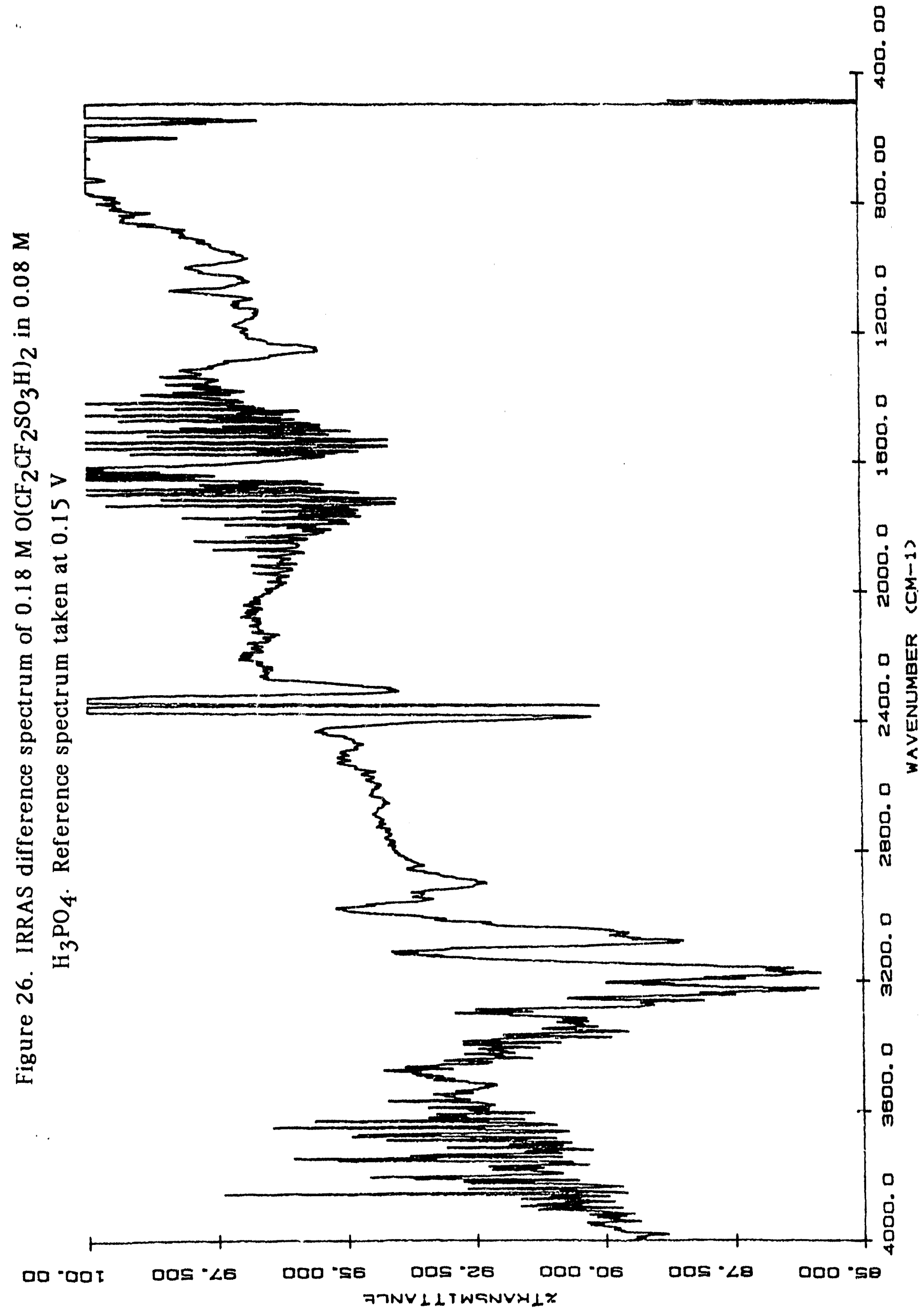


I

สี कू

\&

扂

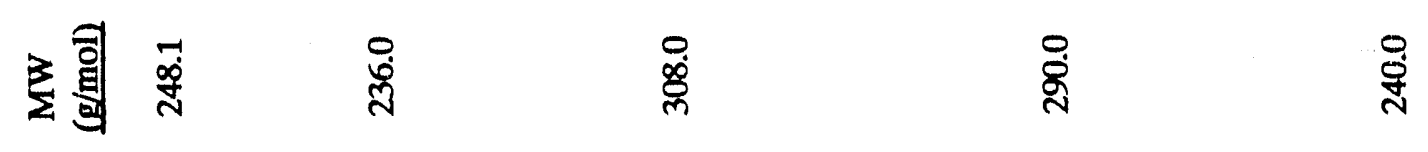

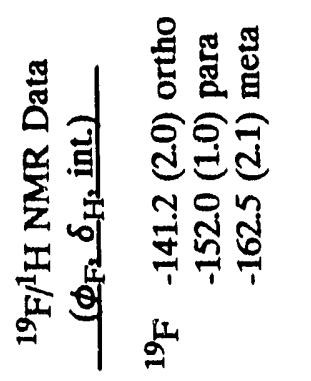

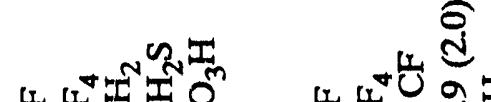

है

क人

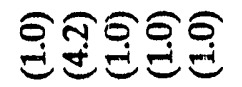

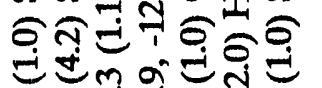

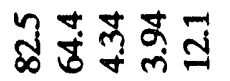

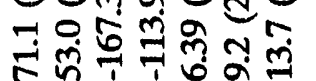

क्ष

2

I

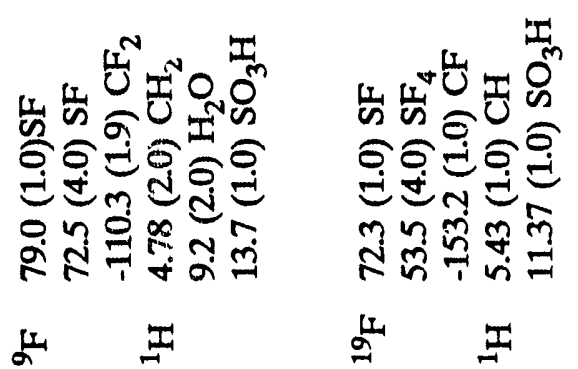

ฮั

宊

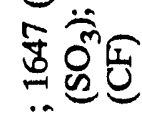

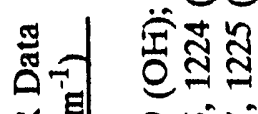

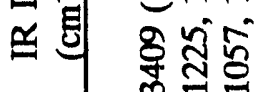

芦密

荃

웅오ㅇㅝㅗ
总

웜

窟逼

窟

搴
芦 窟

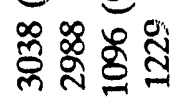

荃焕

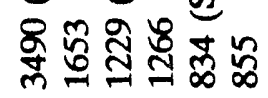

象 鬼

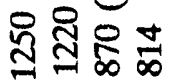

害

察苔刍

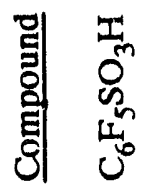
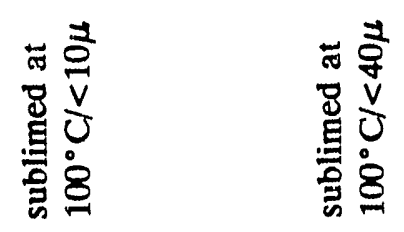

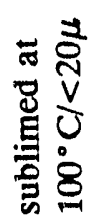

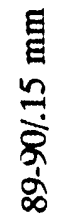
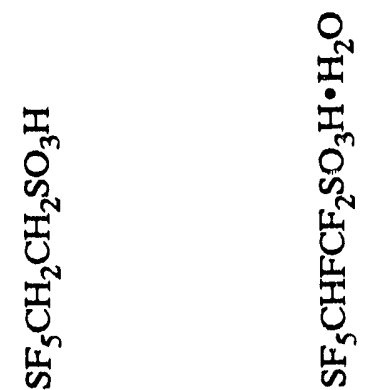

㠭 


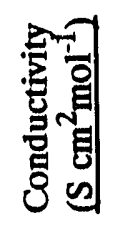

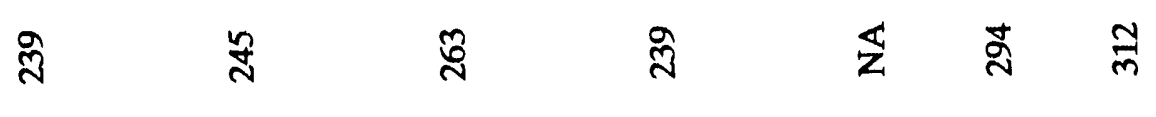

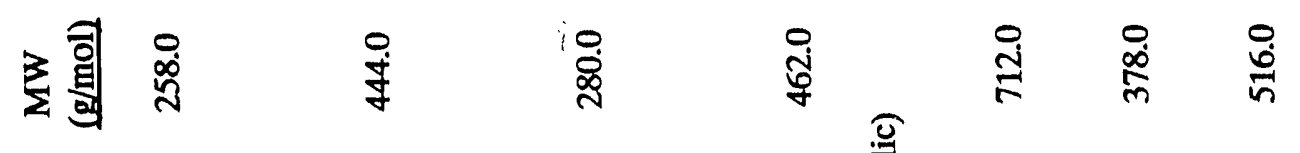

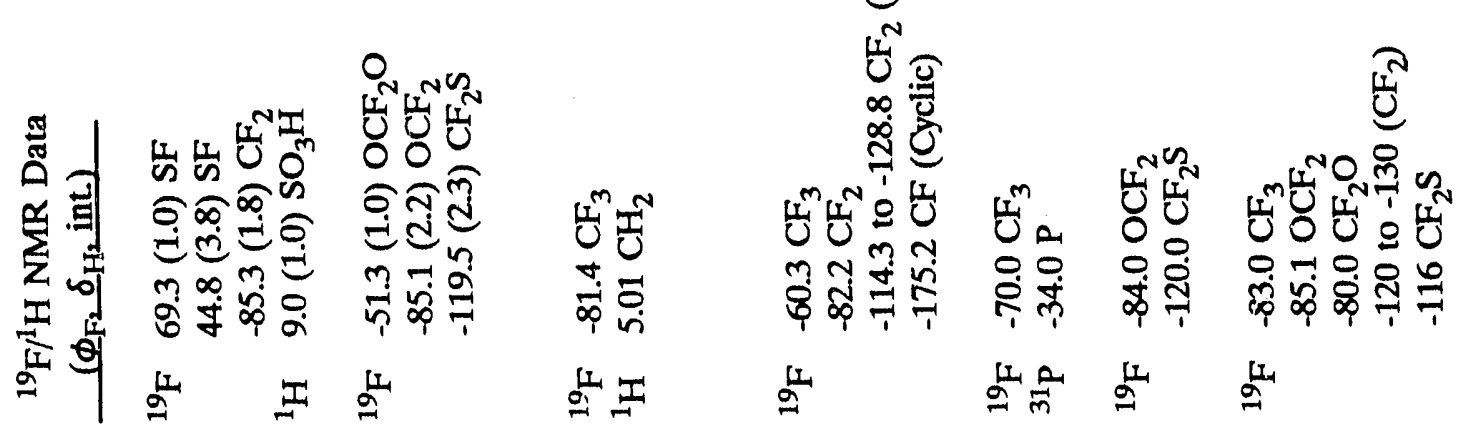

苟

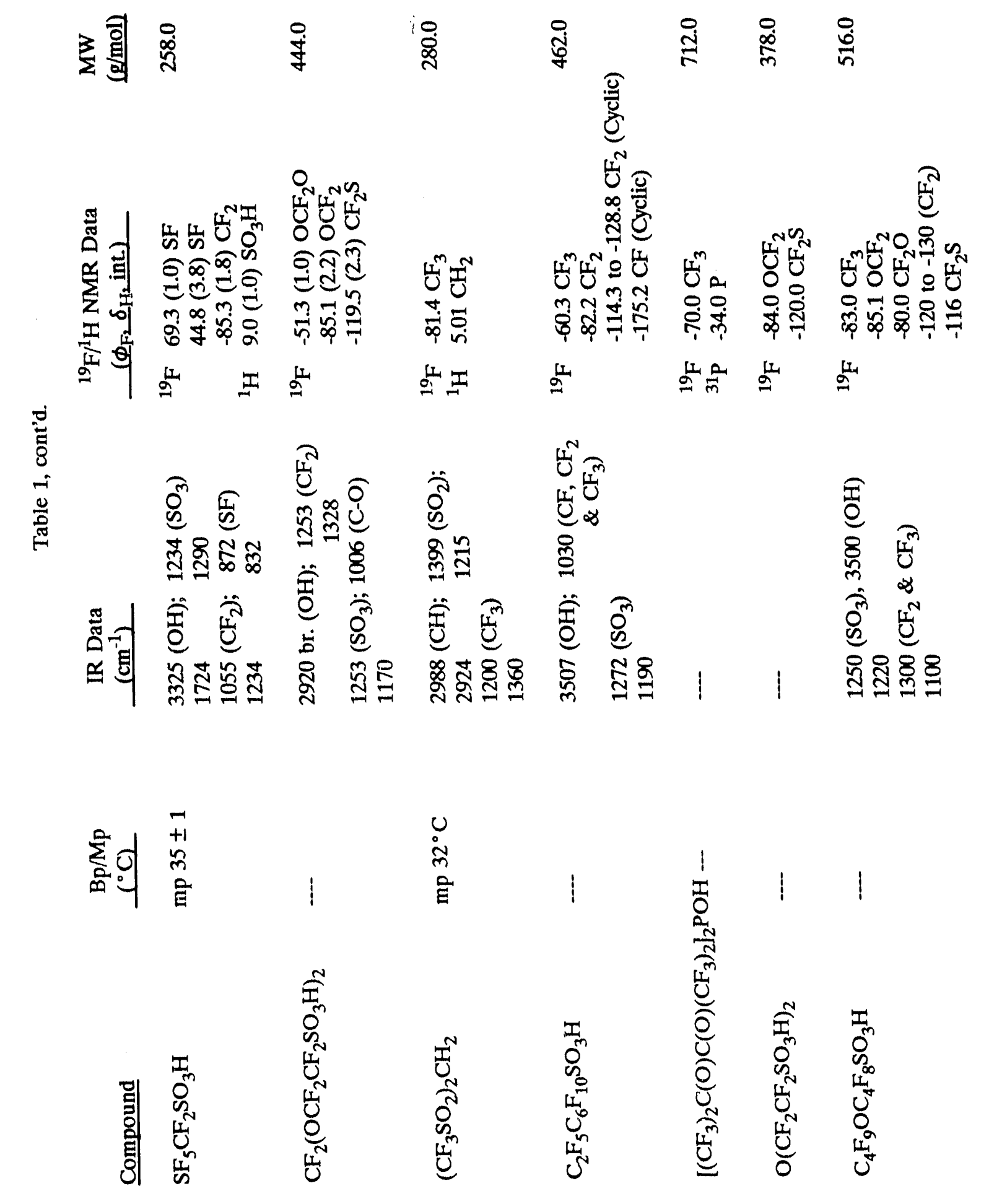




\section{TABLE 2}

Peak currents and potentials of oxygen reduction at Pt electrode in thin solution layer cell. Linear potential scan, $100 \mathrm{~m} \mathrm{~V} / \mathrm{s}$.

$\underline{A C I D}$

$\mathrm{H}_{3} \mathrm{PO}_{4}$
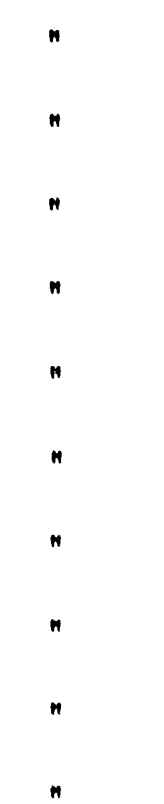

$\mathrm{C}_{7}: \mathrm{H}_{5} \mathrm{SO}_{3} \mathrm{H}$

$\mathrm{C}_{2} \mathrm{~F}_{5}\left(\mathrm{C}_{6} \mathrm{~F}_{10}\right) \mathrm{SO}_{3} \mathrm{H}$

$\mathrm{SF}_{5} \mathrm{CHFSO}_{3} \mathrm{H}$

$\mathrm{SF}_{5} \mathrm{CF}_{2} \mathrm{SO}_{3} \mathrm{H}$

$\mathrm{SF}_{5} \mathrm{CH}_{2} \mathrm{CH}_{2} \mathrm{SO}_{3} \mathrm{H}$

$\mathrm{SF}_{5} \mathrm{CH}_{2} \mathrm{CF}_{2} \mathrm{SO}_{3} \mathrm{H}$

$\mathrm{SF}_{5} \mathrm{CHFCF}_{2} \mathrm{SO}_{3} \mathrm{H}$

$\mathrm{C}_{4} \mathrm{~F}_{9} \mathrm{OC}_{4} \mathrm{~F}_{8} \mathrm{SO}_{3} \mathrm{H}$

$\mathrm{O}\left(\mathrm{CF}_{2} \mathrm{CF}_{2} \mathrm{SO}_{3} \mathrm{H}\right)_{2}$

$\mathrm{CF}_{2}\left(\mathrm{OCF}_{2} \mathrm{CF}_{2} \mathrm{SC}_{3} \mathrm{H}\right)_{2}$
CONC PEAK CURRENT

$0.117 \mathrm{M} \quad 1.85 \mathrm{~mA} / \mathrm{cm}^{2}$

0.115

0.113

0.108

0.961

0.947

0.930

0.884

10.1

9.6

9.2

0.10

0.089

0.386

0.119

0.202

0.146

0.106

0.168

0.150

$0.128 \mathrm{M}$
1.88

1.90

1.93

1.55

1.62

1.65

1.67

0.26

0.29

0.31

1.5

1.85

1.80

1.86

1.22

1.85

1.89

1.47

1.39

$1.54 \mathrm{~mA} / \mathrm{cm}^{2}$
0.74

PEAK POTENTIAL

$0.73 \mathrm{~V}$ vs. RHE

0.76

0.81

ca. $0.4 \quad n$

0.80

0.78

0.72

0.71

0.71

0.74

0.71

$0.71 \mathrm{~V}$ vs. RHE 
Table 2 (cont.)

$\underline{A C I D}$

$\left(\mathrm{CF}_{2} \mathrm{SO}_{2}\right) \mathrm{CH}_{2}$

$\mathrm{CF}_{3} \mathrm{SO}_{3} \mathrm{H}$

$\left(\begin{array}{c}\left(\mathrm{CF}_{3}\right)_{2} \mathrm{C} \\ \mathrm{C}\left(\mathrm{CF}_{3}\right)_{2} \\ \mathrm{O}_{\mathrm{POH}}^{6}\end{array}\right)_{2}$
CONC. PEAK CURRENT PEAK POTENTIAL

0.195

0.101

2.27

0.01 (sat.) $\quad 1.56$
$0.62 \quad n$

$0.81 \quad "$

$0.53 \quad "$

Notes: Temperature was ambient, 22 to $24^{\circ} \mathrm{C}$. Peak currents are the average of 2 to 10 measurements, corrected for background currrents. 
Increase of peak currents of oxygen reduction at Pt electrode in thin solution layer cell with mixtures or acids. Linear potential scans, $100 \mathrm{mV} / \mathrm{s}$.

\begin{tabular}{|c|c|c|c|}
\hline \multicolumn{2}{|c|}{ ACID $\quad$ CONC. RANGE } & \multicolumn{2}{|c|}{$\underline{\mathrm{H}}_{3} \underline{P O}_{4}$ CONC. RANGE PER CENT INCREASE } \\
\hline \multirow[t]{2}{*}{$\mathrm{C}_{2} \mathrm{~F}_{5}\left(\mathrm{C}_{6} \mathrm{~F}_{10}\right) \mathrm{SO}_{3} \mathrm{H}$} & $0-2.4 \mathrm{mM}$ & $0.117-0.114 \mathrm{M}$ & $1.5 \%$ \\
\hline & $\begin{array}{l}0-3.6 \mathrm{mM} \\
0-2.4 \mathrm{mM}\end{array}$ & $\begin{array}{l}0.961-0.92 ? \mathrm{M} \\
10.1-9.82 \mathrm{M}\end{array}$ & $\begin{array}{l}1.0 \% \\
8.3 \%\end{array}$ \\
\hline \multirow[t]{2}{*}{$\mathrm{SF}_{5} \mathrm{CHFSO}_{3} \mathrm{H}$} & $0-63 \mathrm{mM}$ & $0.117-0.115 \mathrm{M}$ & $1.7 \%$ \\
\hline & $\begin{array}{l}0-32 \mathrm{mM} \\
0-226 \mathrm{mM}\end{array}$ & $\begin{array}{l}0.961-0.954 \mathrm{M} \\
10.1-9.5 \mathrm{M}\end{array}$ & $\begin{array}{l}3.0 \% \\
26 \%\end{array}$ \\
\hline \multirow[t]{2}{*}{$\mathrm{SF}_{5} \mathrm{CF}_{2} \mathrm{SO}_{3} \mathrm{H}$} & $0-1.7 \mathrm{mM}$ & $0.117-0.110 \mathrm{M}$ & $<1 \%$ \\
\hline & $\begin{array}{l}0-3.0 \mathrm{mM} \\
0-2.9 \mathrm{mM}\end{array}$ & $\begin{array}{l}0.961-0.856 \mathrm{M} \\
10.1-9.1 \mathrm{M}\end{array}$ & $\begin{array}{l}<1 \% \\
11 \%\end{array}$ \\
\hline \multirow[t]{2}{*}{$\mathrm{SF}_{5} \mathrm{CHFCF}_{2} \mathrm{SO}_{3} \mathrm{H}$} & $0-7.7 \mathrm{mM}$ & $0.117-0.108 \mathrm{M}$ & $2.2 \%$ \\
\hline & $\begin{array}{l}0-6.2 \mathrm{mM} \\
0-12 \mathrm{mM}\end{array}$ & $\begin{array}{l}0.961-0.904 \mathrm{M} \\
10.1-9.0 \mathrm{M}\end{array}$ & $\begin{array}{l}2.0 \% \\
16 \%\end{array}$ \\
\hline \multirow[t]{2}{*}{$\mathrm{CF}_{2}\left(\mathrm{OCF}_{2} \mathrm{CF}_{2} \mathrm{SO}_{3} \mathrm{H}\right)_{2}$} & $0-7.1 \mathrm{mM}$ & $0.117-0.110 \mathrm{M}$ & $2.2 \%$ \\
\hline & $\begin{array}{l}0-12 \mathrm{mM} 0.961-0.872 \mathrm{M} \\
0-8.8 \mathrm{mM}\end{array}$ & $\begin{array}{l}0 \% \\
10.1-8.8 \mathrm{M}\end{array}$ & $0 \%$ \\
\hline \multirow[t]{2}{*}{$\left(\mathrm{CF}_{2} \mathrm{SO}_{2}\right) \mathrm{CH}_{2}$} & $0-3.3 \mathrm{mM}$ & $0.117-0.115 \mathrm{M}$ & $3.8 \%$ \\
\hline & $\begin{array}{l}0-14.5 \mathrm{mM} \\
0-17.9 \mathrm{mM}\end{array}$ & $\begin{array}{l}0.961-0.892 \mathrm{M} \\
10.1-9.2 \mathrm{M}\end{array}$ & $\begin{array}{l}4.8 \% \\
29 \%\end{array}$ \\
\hline \multirow[t]{2}{*}{$\mathrm{CF}_{3} \mathrm{SO}_{3} \mathrm{H}$} & $0-6.8 \mathrm{mM}$ & $0.117-0.109 \mathrm{M}$ & $0 \%$ \\
\hline & $\begin{array}{l}0-7.3 \mathrm{mM} \\
0-7.9 \mathrm{mM}\end{array}$ & $\begin{array}{l}0.961-0.893 \mathrm{M} \\
10.1-0.93 \mathrm{M}\end{array}$ & $\begin{array}{l}0 \% \\
0 \%\end{array}$ \\
\hline
\end{tabular}

Notes for Table 3: Concentration range is the result of adding two or three aliquots of the acid to the phosphoric acid solution. Each current is the averageof two or three measurements and all were corrected for background currents. Increase in peak current calculated from the phosphoric acid data of Table 2, interpolating as necessary. No significant changes, that is $>10 \mathrm{mV}$, in peak potentials were observed. 
Table 4

Oxygen reduction at $\mathrm{Pt}$ rotating disk electrode, $400 \mathrm{rpm}$.

\begin{tabular}{|c|c|c|c|}
\hline$\underline{A C I D}$ & CONC. & LIMITING CURRENT & $\underline{E}_{1 / 2 \text { Vs. RHE }}$ \\
\hline $\mathrm{H}_{3} \mathrm{PO}_{4}$ & $0.085 \mathrm{M}$ & $3.3 \mathrm{~mA} / \mathrm{cm}^{2}$ & $0.72 \mathrm{~V}$ \\
\hline $\mathrm{C}_{6} \mathrm{H}_{5} \mathrm{SO}_{3} \mathrm{H}$ & 0.108 & 3.3 & 0.69 \\
\hline $\mathrm{C}_{2} \mathrm{~F}_{5}\left(\mathrm{C}_{6} \mathrm{~F}_{10}\right) \mathrm{SO}_{3} \mathrm{H}$ & 0.092 & 3.5 & 0.69 \\
\hline $\mathrm{SF}_{5} \mathrm{CHFSO}_{3} \mathrm{H}$ & 0.162 & 3.2 & 0.70 \\
\hline $\mathrm{SF}_{5} \mathrm{CF}_{2} \mathrm{SO}_{3} \mathrm{H}$ & 0.074 & 3.3 & 0.66 \\
\hline $\mathrm{SF}_{5} \mathrm{CH}_{2} \mathrm{CH}_{2} \mathrm{SO}_{3} \mathrm{H}$ & 0.20 & 3.0 & 0.68 \\
\hline $\mathrm{SF}_{5} \mathrm{CH}_{2} \mathrm{CF}_{2} \mathrm{SO}_{3} \mathrm{H}$ & 0.14 & 2.3 & 0.68 \\
\hline $\mathrm{SF}_{5} \mathrm{CHFCF}_{2} \mathrm{SO}_{3} \mathrm{H}$ & 0.10 & 3.2 & 0.71 \\
\hline $\mathrm{C}_{4} \mathrm{~F}_{9} \mathrm{OC}_{4} \mathrm{~F}_{8} \mathrm{SO}_{3} \mathrm{H}$ & 0.17 & 3.3 & 0.73 \\
\hline $\mathrm{O}\left(\mathrm{CF}_{2} \mathrm{CF}_{2} \mathrm{SO}_{3} \mathrm{H}\right)_{2}$ & 0.15 & 3.2 & 0.68 \\
\hline $\mathrm{CF}_{2}\left(\mathrm{OCF}_{2} \mathrm{CF}_{2} \mathrm{SO}_{3} \mathrm{H}\right)_{2}$ & 0.81 & 2.4 & 0.66 \\
\hline$\left(\mathrm{CF}_{2} \mathrm{SO}_{2}\right) \mathrm{CH}_{2}$ & 0.14 & 3.7 & 0.82 \\
\hline
\end{tabular}

Notes: Temperature was ambient, $22-24^{\circ} \mathrm{C}$. Potential scan was initiated from the zero current potential. Limiting currents not corrected for background currents. 


\section{Attachment I \\ Project Publication*}

1. With R. Winter, "Pentafluoro- $\lambda^{6}$-sulfanyl(fluorosulfonyl)ketene", Inorg. Chem., $\underline{27}$, 4329 (1988).

2. With J. Mohtasham, M. Brennen, Z. Yu and J.L. Adcock, "Sulfur Trioxidation of Acyclic Fluoroallyethers: Synthesis of New Fluorinated Sultones and Their Derivatives", J. Fluorine Chem., 43, 349 (1989).

3. With L.F. Chen and J. Mohtasham, "Iodofluoroalkylsulfonyl Fluorides - Synthesis and Conversion to New Derivatives", J. Fluorine Chem., 43, 329 (1989).

4. With R. Winter and R.D. Willett, "Preparation and Crystal Structure of $\left(\mathrm{SF}_{5} \mathrm{CH}_{2} \mathrm{CHO}\right)_{3}$ ", Inorg. Chem., 28, 2499 (1989).

5. With L.F. Chen and J. Mohtasham, "New Polyfluoroalkoxysulfonyl Fluorides-I", J. Fluorine Chem., 46, 21 (1990).

6. With R.J. Willenbring, R. Winter and J. Mohtasham, "Synthesis of New Pentafluorothio $\left(\mathrm{SF}_{5}\right.$ ) Sulfonic Acids", Canadian J. Chem., 67, 2037 (1989).

7. With L.F. Chen and J. Mohtasham, "New Polyfluoroalkoxysulfonyl Fluorides-II", J.Fluorine Chem., 46, 46 (1990).

8. With R. Winter and D.H. Peyton, "Synthesis and Characterization of $\mathrm{F}_{4} \mathrm{~S}=\mathrm{CFCF}_{2} \mathrm{OSO}_{2}$ ", Inorg. Chem., 28, 3766 (1989).

9. With R. Winter, "The Synthesis of $\mathrm{F}_{2} \mathrm{~S}(\mathrm{O}) \mathrm{C}\left(\mathrm{SO}_{2} \mathrm{~F}\right) \mathrm{C}(\mathrm{O}) \mathrm{F}^{\text {", accepted for publication }}$ Inorg. Chem. (1990).

10. With M.R. Pressprich, R.D. Willett, R.J. Terjeson and R. Winter, "Crystal Structure of $\mathrm{SF}_{5} \mathrm{CHFCF}_{2} \mathrm{OSO}_{2}$ ", accepted for publication Inorg. Chem. (1990).

11. With L.F Chen and J. Mohtasham, "New Polyfuoroalkoxysulfonyl Fluorides (Part III)", J. Fluorine Chem., 48, 107 (1990).

12. With J. Mohtasham and F. Behr, "Sulfur Trioxidation of Fluoro-Vinyl Ether: Synthesis of a New Fluorinated $\beta$-Sultone and Derivatives", accepted for publication J. Fluorine Chem. (1990).

13. With L.F. Chen and J. Mohtasham, "New Polyfuoroalkoxysulfonyl Fluorides (Part IV) - Aromatic Derivatives", accepted for publication J. Fluorine Chem. (1990).

14. With J. Mohtasham, Z. Yang and D.J. Burton, "The Synthesis of New Fluorinated $\beta$-Sultone and Its Derivatives from 4,5-Dichloro-1,2-Trifluoropentene", accepted for publication J. Fluorine Chem. (1990).

15. With R. Winter, "The Synthesis of $\mathrm{SF}_{5}$-Epoxides", accepted for publication J. Fluorine Chem. (1990).

16. With R.J. Terjeson, J. Mohtasham, D.H. Peyton, J.P. Canselier, ${ }^{113} \mathrm{C}-\mathrm{NMR}$ Analysis of $\beta$-Fluorosultones", accepted for publication Magn. Res. in Chem. (1990).

17. With A. Waterfeld, R. Mews, J. Mohtasham and R. Winter, "(Pentafluoro- $\lambda^{6}$ sulfanyl)difluoromethane Sulfonyl Fluoride and Derivatives", accepted for publication Inorg. Chem. (1990).

* In publications number 1-6, combined support by GRI and DOE is acknowledged; the remaining publications are attributed to DOE support. 


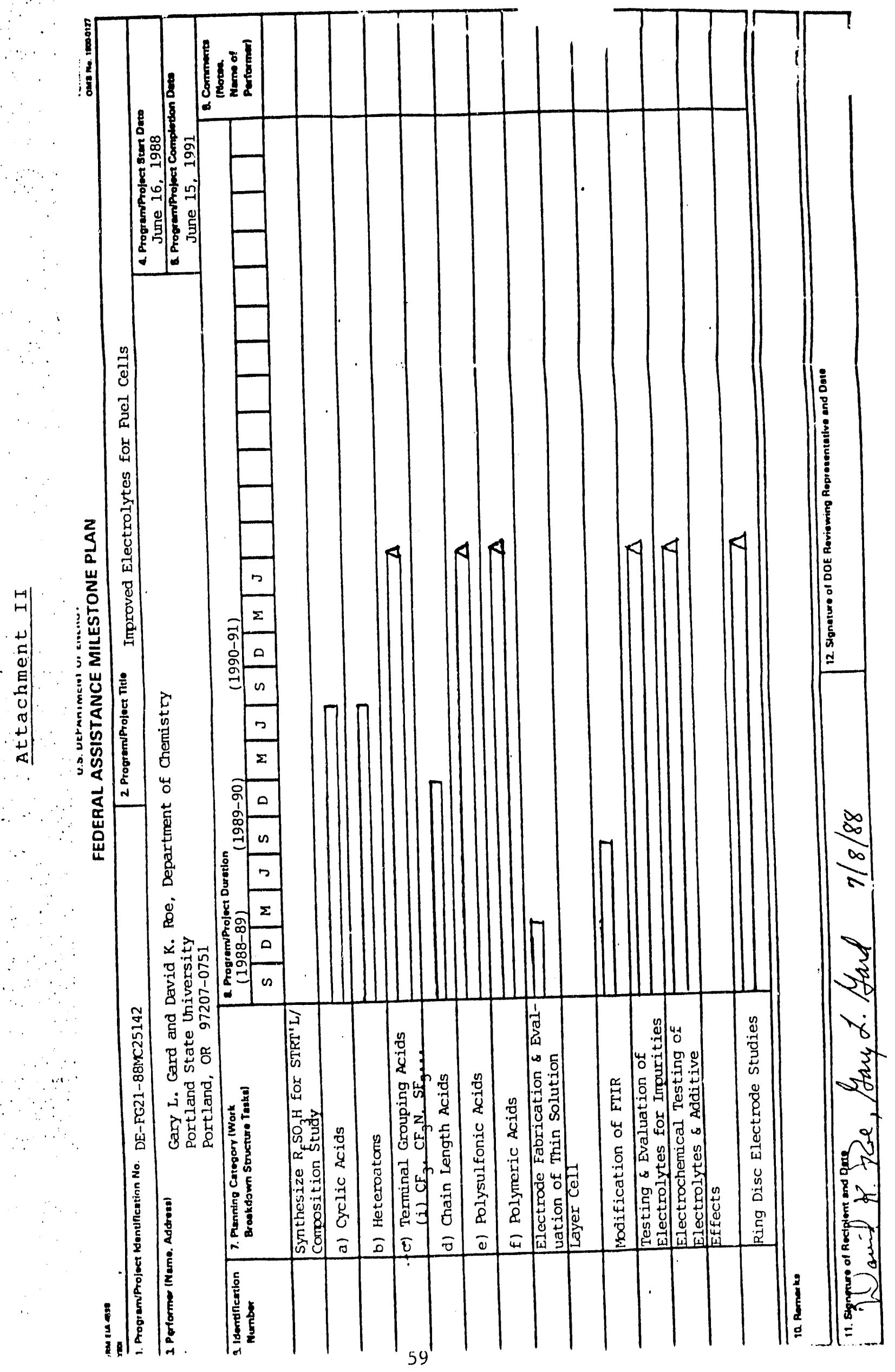




\section{Attachment 3}

Polymeric Sulfonyl Fluoride Esters/Ethers

$\left(\mathrm{CF}_{3} \mathrm{CF}\left(\mathrm{SO}_{2} \mathrm{~F}\right) \mathrm{C}(\mathrm{O}) \mathrm{OCH}_{2} \mathrm{CHCH}_{2}\right)_{\mathrm{n}}$

$\left(\mathrm{SF}_{5} \mathrm{CF}\left(\mathrm{SO}_{2} \mathrm{~F}\right) \mathrm{C}(\mathrm{O}) \mathrm{OCH}_{2} \mathrm{CHCH}_{2}\right)_{\mathrm{n}}$

$\left(\mathrm{SF}_{5} \mathrm{CH}\left(\mathrm{SO}_{2} \mathrm{~F}\right) \mathrm{C}(\mathrm{O}) \mathrm{OCH}_{2} \mathrm{CHCH}_{2}\right)_{\mathrm{n}}$

$\left(\mathrm{FO}_{2} \mathrm{SCF}_{2} \mathrm{C}(\mathrm{O}) \mathrm{OCHCH}_{2}\right)_{\mathrm{n}}$

$\left(\mathrm{CF}_{3} \mathrm{CF}\left(\mathrm{SO}_{2} \mathrm{~F}\right) \mathrm{C}(\mathrm{O}) \mathrm{OCHCH}_{2}\right)_{\mathrm{n}}$

$\left(\mathrm{CF}_{3} \mathrm{O}\left(\mathrm{CF}_{2}\right)_{2} \mathrm{OCF}_{2} \mathrm{CF}\left(\mathrm{SO}_{2} \mathrm{~F}\right) \mathrm{C}(\mathrm{O}) \mathrm{OCH}_{2} \mathrm{CHCH}_{2}\right)_{\mathrm{n}}$

$\left(\mathrm{CF}_{3} \mathrm{OCF}_{2} \mathrm{CF}\left(\mathrm{SO}_{2} \mathrm{~F}\right) \mathrm{C}(\mathrm{O}) \mathrm{OCH}_{2} \mathrm{CHCH}_{2}\right)_{\mathrm{n}}$

$\left.\left(\mathrm{CF}_{2}=\mathrm{CF}\left(\mathrm{CF}_{2}\right)_{2} \mathrm{CF}(\mathrm{S})_{2} \mathrm{~F}\right) \mathrm{C}(\mathrm{O}) \mathrm{OCH}_{2} \mathrm{CHCH}_{2}\right)_{\mathrm{n}}$

$\left(\mathrm{CH}_{2} \mathrm{CHCH}_{2} \mathrm{OC}(\mathrm{O}) \mathrm{CF}\left(\mathrm{SO}_{2} \mathrm{~F}\right)\left(\mathrm{CF}_{2}\right)_{2} \mathrm{CF}\left(\mathrm{SO}_{2} \mathrm{~F}\right) \mathrm{C}(\mathrm{O}) \mathrm{OCH}_{2} \mathrm{CHCH}_{2}\right)_{\mathrm{n}}$

$\left(\mathrm{FO}_{2} \mathrm{SCF}_{2} \mathrm{CF}_{2} \mathrm{OCH}_{2} \mathrm{CHCH}_{2}\right)_{\mathrm{n}}$

$\left(\mathrm{NH}_{2} \mathrm{SO}_{2} \mathrm{CF}_{2} \mathrm{CF}_{2} \mathrm{OCH}_{2} \mathrm{CHCH}_{2}\right)_{\mathrm{n}}$ 

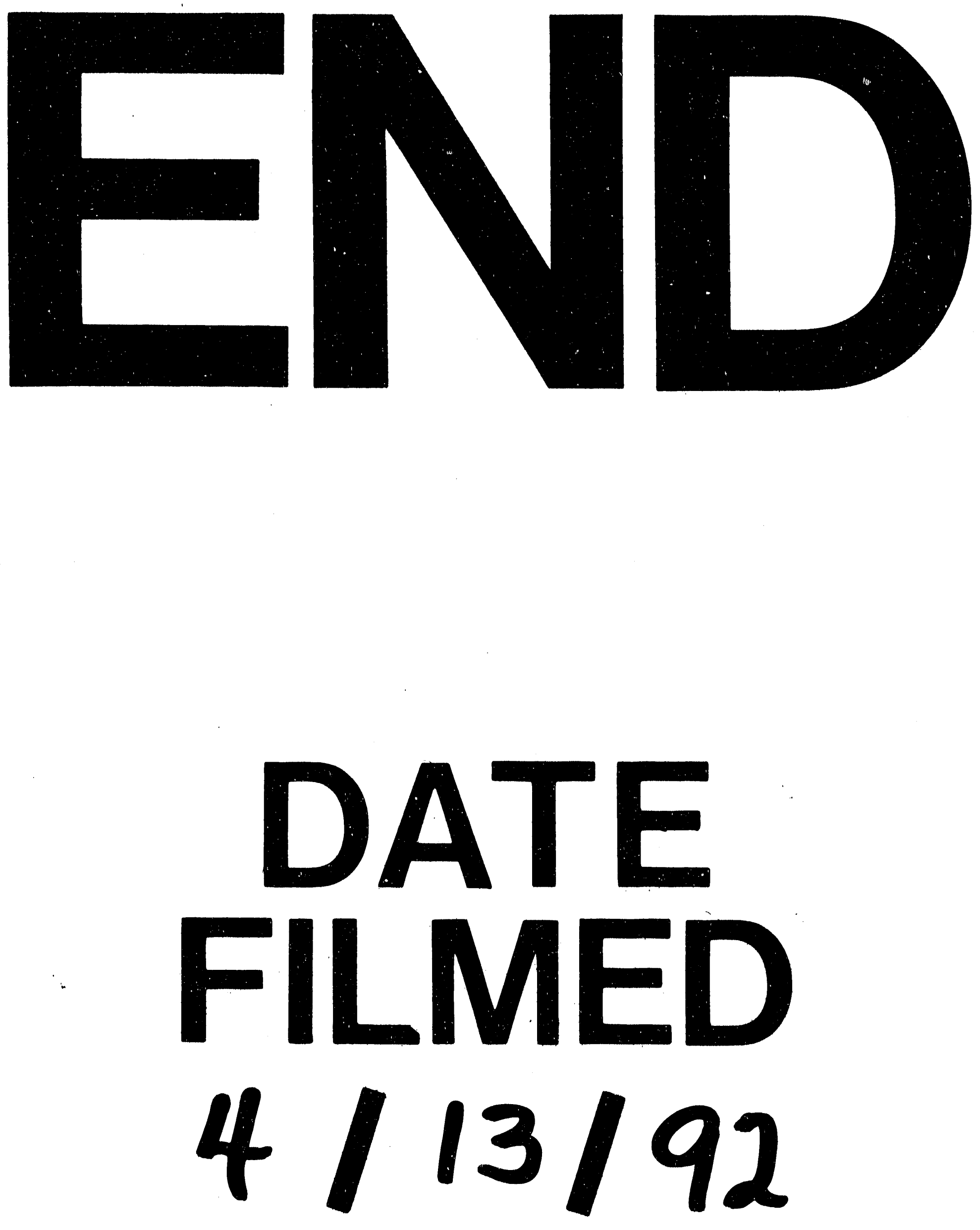
